\title{
THE
}

\section{Half-sandwich ruthenium-arene complexes with thiosemicarbazones: Synthesis and biological evaluation of [(n6-p-cymene)Ru(piperonal thiosemicarbazones)Cl]Cl complexes}

Floyd Beckford

Deidra Dourth

Michael Shaloski Jr.

Jacob Didion

Jeffrey Thessing

Follow this and additional works at: https://digitalcommons.uri.edu/bps_facpubs

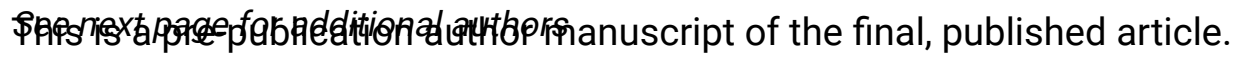

Creative Commons License (c) (i) $\odot$

This work is licensed under a Creative Commons Attribution-Noncommercial-No Derivative Works 4.0 License.

\section{Citation/Publisher Attribution}

Beckford, F., Diourth, D., Shaloski, M. Jr., Didion, J., Thessing, J., Woods, J., Crowell, V.,...Seeram, N. P. (2011). Half-sandwich ruthenium-arene complexes with thiosemicarbazones: Synthesis and biological evaluation of $\left[\left(\eta^{6}-p\right.\right.$-cymene)Ru(piperonal thiosemicarbazones)Cl]Cl complexes. Journal of Inorganic Biochemistry, 105(8), 1019-1029. doi: 10.1016/j.jinorgbio.2011.04.008

Available at: https://doi.org/10.1016/j.jinorgbio.2011.04.008

This Article is brought to you for free and open access by the Biomedical and Pharmaceutical Sciences at DigitalCommons@URI. It has been accepted for inclusion in Biomedical and Pharmaceutical Sciences Faculty Publications by an authorized administrator of DigitalCommons@URI. For more information, please contact digitalcommons@etal.uri.edu. 


\section{Authors}

Floyd Beckford, Deidra Dourth, Michael Shaloski Jr., Jacob Didion, Jeffrey Thessing, Jason Woods, Vernon Crowell, Nikolay Gerasimchuk, Antonio Gonzalez-Sarrías, and Navindra P. Seeram 


\title{
Half-sandwich ruthenium-arene complexes with thiosemicarbazones: Synthesis and biological evaluation of [( $n^{6-}$ p-cymene)Ru(piperonal thiosemicarbazones) $\mathrm{Cl}] \mathrm{Cl}$ complexes
}

\author{
Floyd Beckford ${ }^{a}$, Deidra Dourth ${ }^{\mathrm{a}}$, Michael Shaloski Jr. ${ }^{\mathrm{a}}$, Jacob Didion ${ }^{\mathrm{a}}$, Jeffrey Thessing ${ }^{\mathrm{a}}$, \\ Jason Woods ${ }^{\mathrm{a}}$, Vernon Crowell ${ }^{\mathrm{a}}$, Nikolay Gerasimchuk ${ }^{\mathrm{b}}$, Antonio Gonzalez-Sarrías ${ }^{\mathrm{c}}$, and \\ Navindra P. Seeram ${ }^{c}$ \\ aDivision of Science, Lyon College, 2300 Highland Road, Batesville, AR 72501, USA \\ ${ }^{b}$ Chemistry Department, Missouri State University, 901 South National Avenue, Springfield, MO \\ 65897, USA \\ 'Bioactive Botanical Research Laboratory, Department of Biomedical and Pharmaceutical \\ Sciences, University of Rhode Island, RI 02881, USA
}

\begin{abstract}
The synthesis and characterization of a number of organometallic ruthenium(II) complexes containing a series of bidentate thiosemicarbazone ligands derived from piperonal is reported. The structure of compounds have been confirmed by spectroscopic analysis (IR and NMR) as well as $\mathrm{X}$-ray crystallographic analysis of $\left[\left(\eta^{6}-p\right.\right.$-cymene) $\left.\mathrm{Ru}(\mathrm{pPhTSC}) \mathrm{Cl}\right] \mathrm{Cl}(\mathbf{4})$ (pPhTSC is piperonal$\mathrm{N}(4)$-phenylthiosemicarbazone). The interaction of the complexes $\left(\left[\left(\eta^{6}-p-\right.\right.\right.$ cymene) $\mathrm{Ru}(\mathrm{pEtTSC}) \mathrm{Cl}] \mathrm{Cl})(\mathbf{3})$ (pEtTSC is piperonal-N(4)-ethylthiosemicarbazone) and $\mathbf{4}$ with calf thymus DNA, human serum albumin (HSA) and pBR322 plasmid DNA were studied by spectroscopic, gel electrophoresis and hydrodynamic methods. The apparent binding constant for the interaction with DNA was determined to be $3.97 \times 10^{3} \mathrm{M}^{-1}$ and $4.07 \times 10^{3} \mathrm{M}^{-1}$ at $293 \mathrm{~K}$ for 3 and 4 respectively. The complexes bind strongly to HSA with binding constants of $2.94 \times 10^{4} \mathrm{M}^{-1}$ and $12.2 \times 10^{4} \mathrm{M}^{-1}$ at $296 \mathrm{~K}$ for $\mathbf{3}$ and $\mathbf{4}$ respectively. The in vitro anticancer activity of $\mathbf{3}$ and $\mathbf{4}$ has been evaluated against two human colon cancer cell line (HCT-116 and Caco-2) with IC $_{50}$ values in the range $26-150 \mu \mathrm{M}$. Both 3 and $\mathbf{4}$ show good activity as a catalytic inhibitor of human topoisomerase II at concentrations as low as $20 \mu \mathrm{M}$. The proficiency of $\mathbf{3}$ and $\mathbf{4}$ to act as antibacterial agents was also evaluated against six pathogenic bacterial strains with the best activity seen against Gram-positive strains.
\end{abstract}

\section{Keywords}

Topoisomerase II; human serum albumin; thiosemicarbazone; organometallic ruthenium; anticancer; antibacterial

\footnotetext{
(C) 2011 Elsevier Inc. All rights reserved.

Correspondence to: Floyd Beckford.

Publisher's Disclaimer: This is a PDF file of an unedited manuscript that has been accepted for publication. As a service to our customers we are providing this early version of the manuscript. The manuscript will undergo copyediting, typesetting, and review of the resulting proof before it is published in its final citable form. Please note that during the production process errors may be discovered which could affect the content, and all legal disclaimers that apply to the journal pertain.
} 


\section{Introduction}

Medicinal inorganic chemistry is a discipline of growing importance and the rich diversity of coordination chemistry provides opportunities for the design of new pharmaceuticals. More recently organometallic complexes, initiated by the metallocenes, have been studied intensively (Fig. 1). Titanocene dichloride (I), for instance was in clinical trials but it was difficult to formulate [1]. Ferrocenyl analogues show excellent cytotoxicities in vitro and inhibit the development of tumours in vivo [2]. Other metals have been used as the central metal atom. Organometallic ruthenium $(\mathrm{Ru})$, particularly the half-sandwich complexes like II and III, are emerging as a very promising class of anti-tumour compounds. The geometry of these complexes provide a good scaffold for building new molecules by changing the coordinated arene, the chelated ligand and the chloride group. So compound II, RM175, developed by Sadler et.al. shows anti-cancer activity including activity against cisplatinresistant cell lines [3]. Complexes like III, the so-called RAPTA compounds from the Dyson group, have low in vitro cytotoxicity but show in vivo antimetastic behavior [4].

A modern twist to the idea of combining organometallic and biological components has led to the development of new and promising anticancer drugs. An example of this synergy obtained by modification of a biologically active organometallic fragment with a known drug is the class of compounds known as the ferrocifens developed by Jaouen [5-8]. for adjuvant treatment of hormone-dependent cancers. The compounds are created by appending SERMs (selective estrogen receptor modulators) to a ferrocenyl unit. In particular, hydroxyl ferrocifen (IV) shows anti-proliferative effects on both ER(+) and $\mathrm{ER}(-)$ breast cancer cell cultures, in contrast to the parent tamoxifen. This approach has also been used to create ferroquine - a compound in Phase II clinical trials made by the linking of ferrocene to the anti-malarial chloroquine $[9,10]$.

It has been noted that this strategy of tethering a known drug to a biologically active moiety can endow the drug with new biological properties [11]. In our research group we utilize this strategy by combining the Ru-arene fragment to thiosemicarbazones [12].

Thiosemicarbazones are of considerable pharmacological interest since a number of derivatives have shown a broad spectrum of chemotherapeutic properties. The wide range of biological activities possessed by substituted thiosemicarbazones includes cytotoxic, antitumor [13], antibacterial [14], and antiviral [15] properties. The biological properties of the ligands can be modified and in fact enhanced, by the linkage to metal ions [16-18]. In this paper, we report on a study (synthesis, characterization, structure and biological activity) of a series of half-sandwich organometallic ruthenium complexes containing piperonal thiosemicarbazones as the chelating ligand.

\section{Experimental}

\subsection{Material and Methods}

Analytical or reagent grade chemicals were used throughout. All the chemicals including solvents were obtained from Sigma-Aldrich or other commercial vendors and used as received. Microanalyses (C, H, N) were performed by Columbia Analytical, (Tucson, AZ). Proton and carbon NMR spectra were recorded in dimethylsulfoxide- $d_{6}$ on a Varian Mercury 300 spectrometer operating at room temperature. The residual ${ }^{1} \mathrm{H}$ and ${ }^{13} \mathrm{C}$ present in DMSO- $d_{6}$ (2.50 and $39.51 \mathrm{ppm}$ respectively) were used as internal references. The splitting of proton resonances in the reported ${ }^{1} \mathrm{H}$ NMR spectra is defined as $\mathrm{s}=$ singlet, $\mathrm{d}=$ doublet, $\mathrm{t}=$ triplet, $\mathrm{q}=$ quartet and $\mathrm{wm}=$ wide multiplet. IR spectra in the range $4000-500$ $\mathrm{cm}^{-1}$ were obtained using $\mathrm{KBr}$ pellets or using the ATR accessory on a Nicolet 6700 FTIR spectrophotometer. Cyclic voltammetric $(\mathrm{CV})$ data were collected on a Bioanalytical

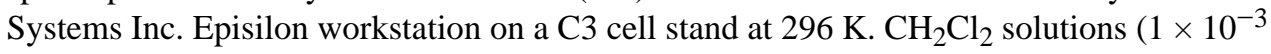


M) containing $0.1 \mathrm{M}$ tetrabutylammonium hexafluorophosphate were saturated with nitrogen for 15 minutes prior to each run. A blanket of nitrogen gas was maintained throughout the measurements. The measurements were carried out with a three-electrode system consisting of a platinum working electrode, a platinum wire auxiliary electrode and a $\mathrm{Ag}-\mathrm{AgCl}$ reference electrode. Ferrocene was used as an internal standard. The working electrode was polished before each experiment with alumina slurry. Fluorescence spectra were recorded on a Varian Cary Eclipse spectrophotometer. Melting points (triplicate measurements) were determined in open capillaries on a Buchi B-545 melting point apparatus and are uncorrected.

\subsection{Syntheses}

The ligands, piperonal thiosemicarbazone (pHTSC), piperonal-N(4)methylthiosemicarbazone (pMeTSC), piperonal-N(4)-ethylthiosemicarbazone (pEtTSC) and piperonal-N(4)-phenylthiosemicarbazone (pPhTSC), were synthesized as follows:

Equimolar amounts piperonal and the appropriate N(4) alkyl-substituted thiosemicarbazide were suspended in $80 \mathrm{~mL}$ of absolute anhydrous ethanol containing a few drops of glacial acetic acid. The reaction mixture was heated at reflux for 3 to $4 \mathrm{~h}$ and a pale yellow suspension resulted. The reaction mixture was cooled and filtered through a glass-sintered crucible. The pale yellow solid which was obtained was washed thoroughly with ethanol followed by ether and air-dried on the vacuum line.

pHTSC-Yield $80 \%$ of an off-white solid. Analysis - Calc for $\mathrm{C}_{9} \mathrm{H}_{9} \mathrm{~N}_{3} \mathrm{O}_{2} \mathrm{~S}: \mathrm{C}, 48.42 ; \mathrm{H}$, 4.06; N, 18.82. Found: C, 48.40; H, 4.02; N, 18.67. m.p. $189^{\circ} \mathrm{C}$. IR $\left(\mathrm{cm}^{-1}\right): v\left(\mathrm{NH}_{2}, \mathrm{NH}\right)$ $3427,3252,3153 ; v(\mathrm{C}=\mathrm{N}) 1592 ; v(\mathrm{C}=\mathrm{S}) 1260,838 .{ }^{1} \mathrm{H}$ NMR $\left(300.08 \mathrm{MHz}, \mathrm{DMSO}-\mathrm{d}_{6}\right): \delta$ $=6.04(2 \mathrm{H}, \mathrm{s}, \mathrm{H} 1), 7.63(1 \mathrm{H}, \mathrm{s}, \mathrm{H} 3), 7.04(1 \mathrm{H}, \mathrm{d} \mathrm{J}=8.4 \mathrm{~Hz}, \mathrm{H} 5), 6.89(1 \mathrm{H}, \mathrm{d} \mathrm{J}=7.8 \mathrm{~Hz}$, H6), $7.92(1 \mathrm{H}, \mathrm{s}, \mathrm{H} 8), 8.01\left(1 \mathrm{H}, \mathrm{s}, \mathrm{N}_{\mathrm{b}} \mathrm{H}\right), 8.04\left(1 \mathrm{H}, \mathrm{s}, \mathrm{N}_{\mathrm{b}} \mathrm{H}\right), 11.3\left(1 \mathrm{H}, \mathrm{s}, \mathrm{N}_{\mathrm{a}} \mathrm{H}\right) .{ }^{13} \mathrm{C}$ NMR (75.463 MHz, DMSO-d 6 ); $\delta=102.01$ (C1), 105.97 (C6), 108.81 (C3), 124.55 (C5), 129.42 (C4), 142.68 (C8), 148.70 (C2), 149.54 (C7), 178.30 (C9)

pMeTSC-Yield 96\% of a pale-yellow solid. Analysis - Calc for $\mathrm{C}_{10} \mathrm{H}_{11} \mathrm{~N}_{3} \mathrm{O}_{2} \mathrm{~S}$ : C, 50.62; H, 4.67; N, 17.71. Found: C, 50.62; H, 4.62; N, 17.50. m.p. $209^{\circ} \mathrm{C}$. IR $\left(\mathrm{cm}^{-1}\right): v\left(\mathrm{NH}_{2}, \mathrm{NH}\right)$ 3344,$3152 ; v(\mathrm{C}=\mathrm{N}) 1590 ; v(\mathrm{C}=\mathrm{S}) 1283,828 .{ }^{1} \mathrm{H}$ NMR $\left(300.08 \mathrm{MHz}, \mathrm{DMSO}-\mathrm{d}_{6}\right): \delta=6.07$ (2H, s, H1), $7.66(1 \mathrm{H}, \mathrm{s}, \mathrm{H} 3), 7.07(1 \mathrm{H}, \mathrm{d} \mathrm{J}=8.1 \mathrm{~Hz}, \mathrm{H} 5), 6.91(1 \mathrm{H}, \mathrm{d} \mathrm{J}=7.8 \mathrm{~Hz}, \mathrm{H} 6), 8.51$ $(1 \mathrm{H}, \mathrm{s}, \mathrm{H} 8), 7.94\left(1 \mathrm{H}, \mathrm{s}, \mathrm{N}_{\mathrm{b}} \mathrm{H}\right), 11.38\left(1 \mathrm{H}, \mathrm{s}, \mathrm{N}_{\mathrm{a}} \mathrm{H}\right), 3.00\left(3 \mathrm{H}, \mathrm{t}, \mathrm{N}_{\mathrm{b}}-\mathrm{CH}_{3}\right) .{ }^{13} \mathrm{C}$ NMR $(75.463$ MHz, DMSO-d $\left.{ }_{6}\right) ; \delta=30.78\left(\mathrm{~N}_{\mathrm{b}}-\mathrm{CH}_{3}\right), 101.47$ (C1), 105.15 (C6), 108.19 (C3), 123.76 (C5), 128.88 (C4), 141.38 (C8), 148.82 (C2), 148.06 (C7), 177.51 (C9).

pEtTSC-Yield $84 \%$ of a pale-yellow solid. Analysis - Calc for $\mathrm{C}_{11} \mathrm{H}_{13} \mathrm{~N}_{3} \mathrm{O}_{2} \mathrm{~S}$ : C, 52.57; H, 5.21; N, 16.72. Found: C, 52.66; H, 5.06; N, 16.58. m.p. $169^{\circ} \mathrm{C}$. IR $\left(\mathrm{cm}^{-1}\right): v\left(\mathrm{NH}_{2}, \mathrm{NH}\right)$ 3375,$3143 ; v(\mathrm{C}=\mathrm{N}) 1589 ; v(\mathrm{C}=\mathrm{S}) 1255,832 .{ }^{1} \mathrm{H}$ NMR $\left(300.08 \mathrm{MHz}, \mathrm{DMSO}-\mathrm{d}_{6}\right): \delta=6.07$ $(2 \mathrm{H}, \mathrm{s}, \mathrm{H} 1), 7.66(1 \mathrm{H}, \mathrm{s}, \mathrm{H} 3), 7.07(1 \mathrm{H}, \mathrm{d} \mathrm{J}=8.1 \mathrm{~Hz}, \mathrm{H} 5), 6.92(1 \mathrm{H}, \mathrm{d} \mathrm{J}=7.8 \mathrm{~Hz}, \mathrm{H} 6), 8.56$ $(1 \mathrm{H}, \mathrm{s}, \mathrm{H} 8), 7.94\left(1 \mathrm{H}, \mathrm{s}, \mathrm{N}_{\mathrm{b}} \mathrm{H}\right), 11.32\left(1 \mathrm{H}, \mathrm{s}, \mathrm{N}_{\mathrm{a}} \mathrm{H}\right), 3.58\left(2 \mathrm{H}, \mathrm{q}, \mathrm{N}_{\mathrm{b}}-\mathrm{CH}_{2}\right), 1.14\left(3 \mathrm{H}, \mathrm{t}, \mathrm{N}_{\mathrm{b}^{-}}\right.$ $\left.\mathrm{CH}_{2}-\mathbf{C H}_{3}\right) .{ }^{13} \mathrm{C}$ NMR $\left(75.463 \mathrm{MHz}\right.$, DMSO-d $\left.{ }_{6}\right) ; \delta=14.72\left(\mathrm{~N}_{\mathrm{b}}-\mathrm{CH}_{2}-\mathbf{C H}_{3}\right), 38.22\left(\mathrm{~N}_{\mathrm{b}}-\mathbf{C H}_{2}-\right.$ $\mathrm{CH}_{3}$ ), 101.47 (C1), 105.23 (C6), 108.19 (C3), 123.78 (C5), 128.84 (C4), 141.50 (C8), 148.83 (C2), 148.05 (C7), 176.46 (C9).

pPhTSC-Yield 94\% of a light-yellow solid. Analysis - Calc for $\mathrm{C}_{15} \mathrm{H}_{13} \mathrm{~N}_{3} \mathrm{O}_{2} \mathrm{~S}: \mathrm{C}, 60.18$; H, 4.38; N, 14.04. Found: C, 60.21; H, 4.50; N, 13.95. m.p. $189^{\circ} \mathrm{C}$. IR $\left(\mathrm{cm}^{-1}\right): v\left(\mathrm{NH}_{2}, \mathrm{NH}\right)$ 3353,$3134 ; v(\mathrm{C}=\mathrm{N}) 1597 ; v(\mathrm{C}=\mathrm{S}) 1253,869 .{ }^{1} \mathrm{H}$ NMR $\left(300.08 \mathrm{MHz}, \mathrm{DMSO}-\mathrm{d}_{6}\right): \delta=6.08$ $(2 \mathrm{H}, \mathrm{s}, \mathrm{H1}), 7.85(1 \mathrm{H}, \mathrm{s}, \mathrm{H} 3), 7.55(1 \mathrm{H}, \mathrm{d} \mathrm{J}=14 \mathrm{~Hz}, \mathrm{H} 5), 7.38(1 \mathrm{H}, \mathrm{d} \mathrm{J}=15 \mathrm{~Hz}, \mathrm{H6}), 8.07$ $(1 \mathrm{H}, \mathrm{s}, \mathrm{H} 8), 10.11\left(1 \mathrm{H}, \mathrm{s}, \mathrm{N}_{\mathrm{b}} \mathrm{H}\right), 11.74\left(1 \mathrm{H}, \mathrm{s}, \mathrm{N}_{\mathrm{a}} \mathrm{H}\right), 6.93-7.25\left(5 \mathrm{H}, \mathrm{m}, \mathrm{N}_{\mathrm{b}}-\mathrm{C}_{6} \mathrm{H}_{5}\right) .{ }^{13} \mathrm{C}$ 
NMR (75.463 MHz, DMSO-d 6 ); $\delta=101.50$ (C1), 105.67 (C6), 108.18 (C3), 142.67 (C8), 149.09 (C2), 148.10 (C7), 175.78 (C9).

2.2.1 Metal complexes-The starting metal compound, $\left[\left(\eta^{6}-p \text {-cymene }\right) \mathrm{RuCl}_{2}\right]_{2}$, was synthesized as described in the literature [19]. The metal complexes were synthesized using a common procedure: The starting ruthenium dimer was dissolved in $15 \mathrm{~mL}$ of dichloromethane and the red solution degassed with argon for 15 minutes. Under a flow of argon, two equivalents of the solid thiosemicarbazone were added and the orange-red mixture stirred for 2 to $3 \mathrm{~h}$ at room temperature. The volume of the reaction mixture was reduced to $\sim 2 \mathrm{~mL}$ and ether (10 to $20 \mathrm{~mL}$ ) was added. The orange-yellow suspension that resulted was filtered and the solid washed with ether and dried at the vacuum line. The orange-red solid may be crystallized from dichloromethane and ether. The solids from the reactions involving pHTSC (1) and pMeTSC (2) appeared hygroscopic and were difficult to handle. The hexafluorophosphate salts of these ligands as well as pPhTSC could be synthesized by incorporating $\mathrm{NH}_{4} \mathrm{PF}_{6}$ (2.5 equiv) at the start of the reaction. These complexes were easier to handle but the elemental analyses (for carbon) were outside the range that is normally acceptable (see Supplemental Information).

[( $\eta^{-}-\mathbf{p}$-cymene)Ru(pHTSC)Cl]Cl.H $\mathbf{H}_{2}$ O (1): Orange solid; "static". Yield: (98\%). Analysis; Calc for $\mathrm{C}_{19} \mathrm{H}_{25} \mathrm{Cl}_{2} \mathrm{~N}_{3} \mathrm{O}_{3} \mathrm{SRu}$ : C, 41.61; H, 4.78; N, 7.66. Found: C, 41.64; H, 4.07; N, 7.49. IR $\left(\mathrm{cm}^{-1}\right): v\left(\mathrm{NH}_{2}, \mathrm{NH}\right) 3258$ (broad, weak); $v(\mathrm{C}=\mathrm{N}) 1594 ; v(\mathrm{C}=\mathrm{S}) 1266,803 .{ }^{1} \mathrm{H}$ NMR $(300.08 \mathrm{MHz}$, DMSO-d 6$): \delta=6.06(2 \mathrm{H}, \mathrm{s}, \mathrm{H} 1), 7.65(1 \mathrm{H}, \mathrm{s}, \mathrm{H} 3), 7.07(1 \mathrm{H}, \mathrm{d} \mathrm{J}=8.4 \mathrm{~Hz}$, H5), $6.90(1 \mathrm{H}, \mathrm{d} \mathrm{J}=7.8 \mathrm{~Hz}, \mathrm{H} 6), 7.94(1 \mathrm{H}, \mathrm{s}, \mathrm{H} 8), 8.04\left(1 \mathrm{H}, \mathrm{s}, \mathrm{N}_{\mathrm{b}} \mathrm{H}\right), 8.13\left(1 \mathrm{H}, \mathrm{s}, \mathrm{N}_{\mathrm{b}} \mathrm{H}\right)$, $11.32\left(1 \mathrm{H}, \mathrm{s}, \mathrm{N}_{\mathrm{a}} \mathrm{H}\right), 5.80\left(\mathrm{~m}, p\right.$-cymene ring), $2.83\left(1 \mathrm{H}, \mathrm{wm}, \mathrm{CH}\left(\mathrm{CH}_{3}\right)_{2}\right), 2.08\left(3 \mathrm{H}, \mathrm{s}, \mathrm{CH}_{3}-\right.$ cymene ring), $1.18\left(\mathrm{~d}, \mathrm{CH}\left(\mathbf{C H}_{3}\right)_{2}\right) .{ }^{13} \mathrm{C}$ NMR $\left(75.463 \mathrm{MHz}, \mathrm{DMSO}_{6}\right) ; \delta=102.08(\mathrm{C} 1)$, 105.99 (C6), 108.83 (C3), 124.56 (C5), 129.45 (C4), 142.62(C8), 148.71 (C2), 149.53 (C7), 178.32 (C9), $86.12-107.02\left(\mathrm{C}_{6} \mathrm{H}_{4}\right), 18.55\left(\mathrm{CH}_{3}-\mathrm{C}_{6} \mathrm{H}_{4}\right), 22.18\left(\mathrm{CH}\left(\mathrm{CH}_{3}\right)_{2}\right), 30.65$ $\left(\mathrm{CH}\left(\mathrm{CH}_{3}\right)_{2}\right)$.

[( $\boldsymbol{\eta}^{\mathbf{6}}-\mathbf{p}$-cymene) $\left.\mathbf{R u}(\mathbf{p M e T S C}) \mathbf{C l}\right] \mathbf{C l}-\mathbf{H}_{2} \mathbf{O}$ (2): Hygroscopic orange-red solid. Yield: (40\%). Analysis; Calc for $\mathrm{C}_{20} \mathrm{H}_{27} \mathrm{Cl}_{2} \mathrm{~N}_{3} \mathrm{O}_{3} \mathrm{SRu}$ : C, 42.78; H, 4.85; N, 7.48. Found: C, 43.00; H, 4.57; N, 7.39. IR $\left(\mathrm{cm}^{-1}\right): v\left(\mathrm{NH}_{2}, \mathrm{NH}\right) 3384(\mathrm{~b}, \mathrm{w}), 3258(\mathrm{~b}, \mathrm{w}) ; v(\mathrm{C}=\mathrm{N}) 1594 ; v(\mathrm{C}=\mathrm{S}) 1266$, 803. : ${ }^{1} \mathrm{H}$ NMR (300.08 MHz, DMSO-d $\left.\mathrm{d}_{6}\right): \delta=6.06(2 \mathrm{H}, \mathrm{s}, \mathrm{H} 1), 7.62(1 \mathrm{H}, \mathrm{s}, \mathrm{H} 3), 7.09(1 \mathrm{H}$, $\mathrm{d} \mathrm{J}=8.1 \mathrm{~Hz}, \mathrm{H} 5), 6.94(1 \mathrm{H}, \mathrm{d} \mathrm{J}=7.8 \mathrm{~Hz}, \mathrm{H6}), 8.46(1 \mathrm{H}, \mathrm{s}, \mathrm{H} 8), 7.96\left(1 \mathrm{H}, \mathrm{s}, \mathrm{N}_{\mathrm{b}} \mathrm{H}\right), 11.31$ $\left(1 \mathrm{H}, \mathrm{s}, \mathrm{N}_{\mathrm{a}} \mathrm{H}\right), 3.02\left(3 \mathrm{H}, \mathrm{t}, \mathrm{N}_{\mathrm{b}}-\mathrm{CH}_{3}\right), 5.80\left(\mathrm{~m}, p\right.$-cymene ring), $2.84\left(1 \mathrm{H}, \mathrm{wm}, \mathrm{CH}\left(\mathrm{CH}_{3}\right)_{2}\right)$, $2.10\left(3 \mathrm{H}, \mathrm{s}, \mathrm{CH}_{3}\right.$-cymene ring), $1.13-1.25\left(\mathrm{~m}, \mathrm{CH}\left(\mathbf{C H}_{3}\right)_{2}\right) .{ }^{13} \mathrm{C} \mathrm{NMR}(75.463 \mathrm{MHz}$, DMSO-d $\left.{ }_{6}\right) ; \delta=30.69\left(\mathrm{~N}_{\mathrm{b}}-\mathrm{CH}_{3}\right), 102.17(\mathrm{C} 1), 105.85(\mathrm{C} 6), 108.86(\mathrm{C} 3), 124.48(\mathrm{C} 5)$, 129.61(C4), 142.09 (C8), 149.53(C2), 148.78 (C7), 178.23 (C9), $86.12-107.07\left(\mathrm{C}_{6} \mathrm{H}_{4}\right)$, $18.61\left(\mathrm{CH}_{3}-\mathrm{C}_{6} \mathrm{H}_{4}\right), 22.21\left(\mathrm{CH}\left(\mathrm{CH}_{3}\right)_{2}\right), 31.46\left(\mathrm{CH}\left(\mathrm{CH}_{3}\right)_{2}\right)$.

[(n- ${ }^{6}-\mathbf{p}$-cymene)Ru(pEtTSC)CI]Cl (3): Orange-yellow solid. Yield: (73\%). Analysis; Calc for $\mathrm{C}_{21} \mathrm{H}_{27} \mathrm{Cl}_{2} \mathrm{~N}_{3} \mathrm{O}_{2} \mathrm{SRu}$ : C, 45.24; H, 4.88; N, 7.46. Found: C, 45.17; H, 4.48; N, 7.46. m.p. $156{ }^{\circ} \mathrm{C}$ (char). IR $\left(\mathrm{cm}^{-1}\right): v\left(\mathrm{NH}_{2}, \mathrm{NH}\right) 3197(\mathrm{~b}, \mathrm{w}) ; v(\mathrm{C}=\mathrm{N}) 1594 ; v(\mathrm{C}=\mathrm{S}) 1267,799 .{ }^{1} \mathrm{H}$ NMR $\left(300.08 \mathrm{MHz}\right.$, DMSO-d $\left.{ }_{6}\right): \delta=11.33\left(1 \mathrm{H}, \mathrm{s}, \mathrm{N}_{\mathrm{a}} \mathrm{H}\right), 8.58(1 \mathrm{H}, \mathrm{s}, \mathrm{H} 8), 7.96(1 \mathrm{H}, \mathrm{s}$, $\left.\mathrm{N}_{\mathrm{b}} \mathrm{H}\right), 7.66(1 \mathrm{H}, \mathrm{s}, \mathrm{H} 3), 7.08(1 \mathrm{H}, \mathrm{d}, \mathrm{H} 5), 6.96(1 \mathrm{H}, \mathrm{d}, \mathrm{H} 6), 6.08(2 \mathrm{H}, \mathrm{s}, \mathrm{H} 1), 5.82(4 \mathrm{H}, \mathrm{m}, p-$ cymene ring), $3.58\left(2 \mathrm{H}, \mathrm{m}, \mathrm{N}_{\mathrm{b}}-\mathrm{CH}_{2}\right), 2.84\left(1 \mathrm{H}, \mathrm{wm}, \mathrm{CH}\left(\mathrm{CH}_{3}\right)_{2}\right), 2.09\left(3 \mathrm{H}, \mathrm{s}, \mathrm{CH}_{3}\right.$-cymene ring), $1.14-1.18\left(\mathrm{~m}, \mathrm{~N}_{\mathrm{b}}-\mathrm{CH}_{2}-\mathbf{C H}_{3}\right)$ and $\left.\mathrm{CH}\left(\mathbf{C H}_{3}\right)_{2}\right) .{ }^{13} \mathrm{C} \mathrm{NMR}\left(75.463 \mathrm{MHz}\right.$, DMSO-d $\left.{ }_{6}\right)$; $\delta=14.71\left(\mathrm{~N}_{\mathrm{b}}-\mathrm{CH}_{2}-\mathbf{C H}_{3}\right), 38.19\left(\mathrm{~N}_{\mathrm{b}}-\mathbf{C H}_{2}-\mathrm{CH}_{3}\right), 101.46(\mathrm{C} 1), 105.23(\mathrm{C} 6), 108.20(\mathrm{C} 3)$, 123.78 (C5), 128.83 (C4), 141.47 (C8), 148.81 (C2), 148.04 (C7), 176.43 (C9), 85.52 $106.35\left(\mathrm{C}_{6} \mathrm{H}_{4}\right), 17.89\left(\mathrm{CH}_{3}-\mathrm{C}_{6} \mathrm{H}_{4}\right), 21.52\left(\mathrm{CH}\left(\mathrm{CH}_{3}\right)_{2}\right), 29.99\left(\mathbf{C H}\left(\mathrm{CH}_{3}\right)_{2}\right)$ 
[(n--p-cymene)Ru(pPhTSC)Cl]Cl (4): Orange-yellow solid. Yield: (79\%). Crystals suitable for $\mathrm{X}$-ray analysis were grown by slow diffusion of ether into a concentrated dichloromethane solution. Analysis; Calc for $\mathrm{C}_{25} \mathrm{H}_{27} \mathrm{Cl}_{2} \mathrm{~N}_{3} \mathrm{O}_{2} \mathrm{SRu}$ : C, 49.59; $\mathrm{H}, 4.49 ; \mathrm{N}$, 6.94. Found: C, 49.13; H, 4.14; N, 6.87. m.p. $174{ }^{\circ} \mathrm{C}$ (charring). IR $\left(\mathrm{cm}^{-1}\right): v\left(\mathrm{NH}_{2}, \mathrm{NH}\right)$ 3188 (broad, weak); $v(\mathrm{C}=\mathrm{N}) 1577 ; v(\mathrm{C}=\mathrm{S}) 1266,822 .{ }^{1} \mathrm{H}$ NMR $\left(300.08 \mathrm{MHz}\right.$, DMSO-d $\left.{ }_{6}\right)$ : $\delta=11.71\left(1 \mathrm{H}, \mathrm{s}, \mathrm{N}_{\mathrm{a}} \mathrm{H}\right), 10.09\left(1 \mathrm{H}, \mathrm{s}, \mathrm{N}_{\mathrm{b}} \mathrm{H}\right), 8.05(1 \mathrm{H}, \mathrm{s}, \mathrm{H} 8), 7.83(1 \mathrm{H}, \mathrm{s}, \mathrm{H} 3), 7.52(1 \mathrm{H}, \mathrm{d}$, H5), $7.34(1 \mathrm{H}, \mathrm{d}, \mathrm{H} 6), 7.12-7.21\left(\mathrm{~m}, \mathrm{C}_{6} \mathrm{H}_{5}\right), 6.07(2 \mathrm{H}, \mathrm{s}, \mathrm{H} 1), 5.79$ (m, $p$-cymene ring), $2.72\left(1 \mathrm{H}\right.$, wm, $\left.\mathrm{CH}\left(\mathrm{CH}_{3}\right)_{2}\right), 2.07\left(3 \mathrm{H}, \mathrm{s}, \mathrm{CH}_{3}\right.$-cymene ring), $1.18\left(6 \mathrm{H}, \mathrm{d}, \mathrm{CH}\left(\mathbf{C H}_{3}\right)_{2}\right) .{ }^{13} \mathrm{C}$ NMR (75.463 MHz, DMSO-d 6 ); $\delta=101.47$ (C1), 105.59 (C6), 106.33 (C3), 123.78 (C5), 128.84 (C4), 142.65 (C8), 149.07 (C2), 148.08 (C7), 175.75 (C9), 85.52 - $106.35\left(\mathrm{C}_{6} \mathrm{H}_{4}\right)$, $17.88\left(\mathrm{CH}_{3}-\mathrm{C}_{6} \mathrm{H}_{4}\right), 21.51\left(\mathrm{CH}\left(\mathrm{CH}_{3}\right)_{2}\right), 29.99\left(\mathbf{C H}\left(\mathrm{CH}_{3}\right)_{2}\right)$.

\subsection{X-ray crystallography}

X-ray crystallographic data were collected at $296( \pm 1) \mathrm{K}$ on a Bruker APEX CCD diffractometer with Mo K $\alpha$ radiation $(\lambda=0.71073 \AA)$ and a detector-to-crystal distance of $4.94 \mathrm{~cm}$. Data collection was optimized utilizing the APEX 2 software [20] with $0.5^{\circ}$ rotation between frames and an exposure time of $10 \mathrm{~s}$ per frame. The structures were solved by direct methods and refined using SHELXTL 6.10 [20]. Data integration, correction for Lorentz and polarization effects, and final cell refinement was performed using SAINTPLUS, and corrected for absorption using SADABS. All non-hydrogen atoms were refined anisotropically and hydrogen atoms placed in calculated positions. Crystallographic data and data collection parameters are listed in Table 1. A complete list of bond lengths and angles may be found in the Supporting Information.

\subsection{DNA-interaction studies}

All the experiments involving the interaction of the complexes with DNA were carried out in TRIS buffer ( $5 \mathrm{mM}$ Tris, $50 \mathrm{mM} \mathrm{NaCl}, \mathrm{pH}$ 7.20). Stock solutions of ct-DNA was prepared by dissolving commercial nucleic acids in buffer and stored at $4{ }^{\circ} \mathrm{C}$ for $24 \mathrm{~h}$ to attain homogeneity. After dilutions DNA concentration per nucleotide phosphate was determined spectrophotometrically using the molar absorption coefficient of $6600 \mathrm{M}^{-1} \mathrm{~cm}^{-1}$ at $260 \mathrm{~nm}$ [21]. A solution of ct-DNA in the buffer gave a ratio of UV absorbance at 260 and $280 \mathrm{~nm}$ of $\geq 1.8$ indicating that the DNA was sufficiently free from protein contamination [22]. The DNA stock solutions were stored at $4{ }^{\circ} \mathrm{C}$ and used within 4 days after their preparation. Doubly purified water used in all experiment was from a Milli-Q system.

2.4.1 Viscosity measurements-Viscosity studies were done using a Cannon-Manning semi micro-dilution viscometer (type 75, Cannon Instruments Co., State College, PA, USA) immersed vertically in a thermostatted water bath maintained at $31.0 \pm 0.1{ }^{\circ} \mathrm{C}$. The viscosity for DNA was measured in the presence and absence of the metal complexes. The DNA concentration was maintained at $100 \mu \mathrm{M}$, while the complex concentration was varied from $0-60 \mu \mathrm{M}$. Data are presented as $\left(\eta / \eta_{0}\right)^{1 / 3}$ versus $1 / \mathrm{R}$, where $\mathrm{R}=[\mathrm{DNA}] /[$ complex $]$ and $\eta$ is the viscosity of DNA in the presence of the complex and $\eta_{0}$ is the relative viscosity of DNA alone. Relative viscosity values were calculated from the observed flow time of DNA solution ( $t$ ) and corrected for the flow time of buffer alone (t0), using the expression $\eta_{0}=(t-$ $\left.\mathrm{t}_{0}\right) / \mathrm{t}_{0}$. Flow time was measured with a digital stopwatch and each sample was measured three times and an average flow time was used.

2.4.2 Ethidium bromide and Hoechst 33258 displacement experiments-In the ethidium bromide (EB) fluorescence displacement experiment, $3 \mathrm{~mL}$ of a solution that is 10 $\mu \mathrm{M}$ DNA and $0.33 \mu \mathrm{M}$ EB (saturated binding levels) [23], in TRIS buffer was titrated with concentrated solutions of the complexes producing the solutions with various mole ratios of 
complex to ct-DNA. After each addition the solution was stirred at the appropriate temperature for 5 minutes before measurement. The fluorescence spectra of the solution were obtained by exciting at $520 \mathrm{~nm}$ and measuring the emission spectra from 530 to 700 $\mathrm{nm}$ using $5 \mathrm{~nm}$ slits. Temperature was controlled using a single-cell Peltier accessory. The procedure was the same for the Hoechst 33258 reactions using the following conditions: working solutions were $20 \mu \mathrm{M}$ DNA and $2 \mu \mathrm{M}$ Hoechst $33258 ; \lambda_{\mathrm{ex}}=338 \mathrm{~nm}$ and $\lambda_{\mathrm{em}}=400$ to $550 \mathrm{~nm}$ (with $\lambda_{\max }=464 \mathrm{~nm}$ ).

2.4.3 Chemical nuclease activity-The DNA unwinding and cleavage ability of the complexes was evaluated by agarose gel electrophoresis of supercoiled pBR322 DNA. The experiments were done in the dark or with exposure to long-radiation UV light. Samples of pBR322 DNA $(0.1 \mu \mathrm{g} / \mu \mathrm{L})$ were incubated with the complexes (in concentration ranging from 10 to $300 \mu \mathrm{M}$ ) in TRIS buffer (50 mM Tris, $18 \mathrm{mM} \mathrm{NaCl}$, pH 8.2) at room temperature for $1 \mathrm{~h}$ in the dark or subjected to $365 \mathrm{~nm}$ light. Samples containing sodium formate $(400 \mathrm{mM})$, potassium iodide $(400 \mathrm{mM})$ and sodium azide $(100 \mathrm{mM})$ were included in the experiments. The reactions were quenched by addition of $3 \mu \mathrm{L}$ of loading buffer ( $0.25 \%$ bromophenol blue and $15 \%$ Ficoll in water). Samples of the reaction mixtures were loaded onto a $1 \%$ agarose gel in TBE buffer ( $89 \mathrm{mM}$ Tris, $89 \mathrm{mM}$ boric acid, $2 \mathrm{mM}$ EDTA, $\mathrm{pH}$ 8.2). The gels were subjected to electrophoresis for $1 \mathrm{~h}$ at $70 \mathrm{~V}$, followed by staining with $0.5 \mu \mathrm{g} / \mathrm{mL}$ ethidium bromide for $30 \mathrm{~min}$. The bands on the gel were visualized under UV light and photographed using a GEL Logic 440 Imaging System with a Kodak Molecular Imaging Software.

\subsection{Activity against topoisomerase II}

The capability of the ruthenium complexes to affect topoisomerase II activity was analyzed using gel electrophoresis. The reaction mixture was a total of $20 \mu \mathrm{L}$ TRIS buffer $(50 \mathrm{mM}$ Tris, $18 \mathrm{mM} \mathrm{NaCl}, \mathrm{pH}$ 7.2) was used as the reaction buffer for the complexes. The "complete buffer" was made fresh daily by adding equal volumes of 10x Topo II Assay Buffer A (0.5 M Tris- $\mathrm{HCl}(\mathrm{pH} 8), 1.50 \mathrm{M} \mathrm{NaCl}, 100 \mathrm{mM} \mathrm{MgCl}_{2}, 5 \mathrm{mM}$ dithiothreitol and $300 \mu \mathrm{g} \mathrm{BSA} / \mathrm{mL}$ ) to the 10x ATP Buffer B (20 mM ATP in water) and was used at $1 / 5$ volume. The metal complexes were added to yield varying concentrations $(20 \mu \mathrm{M}, 50 \mu \mathrm{M}$, $100 \mu \mathrm{M}$, and $300 \mu \mathrm{M}$ ) from a $3 \mathrm{mM}$ stock solution made fresh in a 1:1 solution of DMSO and TRIS buffer. Etoposide used as a control poison was added from a $10 \mathrm{mM}$ stock solution in DMSO to create a $1 \mathrm{mM}$ concentration in the reaction. Also a control lane, in which DMSO was added to DNA at the highest concentration it appears in a single reaction, was included. DNA (pHOT-1) was used at a concentration of $12.5 \mathrm{ng} / \mu 1$. Human topoisomerase II $\alpha$ ( 3 units, $1.5 \mu \mathrm{l}$ ) was added and the reactions were immediately transferred from the ice bath to a $37^{\circ} \mathrm{C}$ hot water bath for $30 \mathrm{~min}$. The reactions were terminated by adding $1 / 10$ volume of $10 \%$ sodium dodecyl sulphate. Proteinase K was added at a concentration of $50 \mu \mathrm{g} / \mathrm{ml}$. The reactions were incubated in the hot water bath for an additional $15 \mathrm{~min} .1 / 10$ volume of $10 \mathrm{x}$ gel loading buffer was added and the reactions removed from the water bath. They were cleaned up via a CIA extraction. An equal volume of CIA (chloroform: isoamyl alcohol 24:1) was added, the mixture vortexed and then briefly centrifuged. The upper blue layer was split in half and placed into corresponding wells of two $1 \%$ agarose gels in TRIS-Borate-EDTA buffer (TBE). One gel contained $0.2 \mu \mathrm{g} / \mathrm{ml}$ ethidium bromide. The gels were run at $70 \mathrm{~V}$ for $2 \mathrm{~h}$ in TBE. The EB gel was run with TBE containing $0.5 \mu \mathrm{g} / \mathrm{ml}$ ethidium bromide. This gel was then de-stained in DNA-free water for $30 \mathrm{~min}$ while the other gel was stained in an ethidium bromide/buffer solution for $30 \mathrm{~min}$. It was then de-stained as mentioned before. The bands on the gel were imaged under UV light using a GEL Logic 440 Imaging System with Kodak Molecular Imaging Software. 


\subsection{Reaction with human serum albumin (HSA)}

2.6.1 Fluorescence titration-For the fluorescence titration, a similar procedure to the EB displacement experiments was done. Solutions of HSA (fatty acid-free) were prepared in TRIS buffer $(50 \mathrm{mM}$ TRIS, pH 7.40, $100 \mathrm{mM} \mathrm{NaCl})$ and stored in the dark at $4{ }^{\circ} \mathrm{C}$. The protein concentration was determined spectrophotometrically using the molar absorptivity of $3.6 \times 10^{4} \mathrm{M}^{-1} \mathrm{~cm}^{-1}$ at $280 \mathrm{~nm}$ [24]. In the experiments, a $3.0 \mathrm{~mL}$ solution of HSA $(5 \mu \mathrm{M})$ was placed in a quartz cuvette and titrated with various amounts of a concentrated solution of the complex producing the solutions with varied mole ratios of complex to HSA. The complex concentration ranged from 3 to $30 \mu \mathrm{M}$. The fluorescence spectra of the solutions were obtained by exciting at $295 \mathrm{~nm}$ and measuring the emission spectra from $300-500$ nm.

2.6.2 Infrared spectrophotometry-IR spectra in the range 1200 to $2000 \mathrm{~cm}^{-1}$ were obtained using the ATR accessory (with a germanium crystal) on a Nicolet 6700 FTIR spectrophotometer equipped with a DTGS KBr detector and a $\mathrm{KBr}$ beam splitter. The infrared spectra of HSA, HSA plus the complex (1:1 molar ratio) and the complex alone were recorded. The HSA-complex solutions were incubated for $24 \mathrm{~h}$ prior to measurement. The absorbance of the buffer was subtracted from the spectra of the solutions. Then difference spectra were calculated using the instrument's software package.

\subsection{Cell culture}

Cell lines included two human colon cancer cells: HCT116 (human colon carcinoma) and Caco-2 (human epithelial colorectal adenocarcinoma). In addition, normal human colon cells CCD-18Co (human colon fibroblasts), were included. All cell lines were obtained from the American Type Culture Collection (ATCC, Rockville, MD, USA) and maintained at the University of Rhode Island. Caco-2 cells were grown in EMEM medium supplemented with $10 \% \mathrm{v} / \mathrm{v}$ foetal bovine serum, $1 \% \mathrm{v} / \mathrm{v}$ nonessential amino acids, $1 \% \mathrm{v} / \mathrm{v}$ L-glutamine and $1 \%$ $\mathrm{v} / \mathrm{v}$ antibiotic solution (Sigma). HCT-116 cells were grown in McCoy's 5a medium supplemented with $10 \% \mathrm{v} / \mathrm{v}$ foetal bovine serum, $1 \% \mathrm{v} / \mathrm{v}$ nonessential amino acids, $2 \% \mathrm{v} / \mathrm{v}$ HEPES and $1 \% \mathrm{v} / \mathrm{v}$ antibiotic solution. CCD-18Co cells were grown in EMEM medium supplemented with $10 \% \mathrm{v} / \mathrm{v}$ foetal bovine serum, $1 \% \mathrm{v} / \mathrm{v}$ nonessential amino acids, $1 \% \mathrm{v} / \mathrm{v}$ L-glutamine and $1 \% \mathrm{v} / \mathrm{v}$ antibiotic solution and were used from $\mathrm{PDL}=26$ to $\mathrm{PDL}=35$ for all experiments. Cells were maintained at $37{ }^{\circ} \mathrm{C}$ in an incubator under a $5 \% \mathrm{CO}_{2} / 95 \%$ air atmosphere at constant humidity and maintained in the linear phase of growth. The $\mathrm{pH}$ of the culture medium was determined using $\mathrm{pH}$ indicator paper (pHydrion ${ }^{\mathrm{TM}}$ Brilliant, $\mathrm{pH} 5.5-$ 9.0, Micro Essential Laboratory, NY, USA) inside the incubator. All of the test samples were solubilized in DMSO ( $<0.5 \%$ in the culture medium) by sonication and were filter sterilized $(0.2 \mu \mathrm{m})$ prior to addition to the culture media. Control cells were also run in parallel and subjected to the same changes in medium with a $0.5 \%$ DMSO.

2.7.1 Cytotoxicity assay-The assay was carried out as described previously [25] to measure the $\mathrm{IC}_{50}$ values for samples. Briefly, the in vitro cytotoxicity of samples were assessed in tumour cells by a tetrazolium-based colorimetric assay, which takes advantage of the metabolic conversion of MTS [3-(4,5-dimethylthiazol-2-yl)-5-(3carboxymethoxyphenyl)-2-(4-sulfenyl)- $2 \mathrm{H}$-tetrazolium, inner salt] to a reduced form that absorbs light at $490 \mathrm{~nm}$. Cells were counted using a haemocytometer and were plated at 2,000 to 5,000 cells per well, depending on the cell line, in a 96-well format for $24 \mathrm{~h}$ prior to drug addition. Test samples and a positive control, etoposide $4 \mathrm{mg} / \mathrm{mL}$ (Sigma), were solubilized in DMSO by sonication. All samples were diluted with media to the desired treatment concentration and the final DMSO concentration per well did not exceed $0.5 \%$. Control wells were also included on all plates. Following a $24 \mathrm{~h}, 48 \mathrm{~h}$ or $72 \mathrm{~h}$ drugincubation period at $37{ }^{\circ} \mathrm{C}$ with serially diluted test compounds, MTS, in combination with 
the electron coupling agent, phenazine methosulfate, was added to the wells and cells were incubated at $37^{\circ} \mathrm{C}$ in a humidified incubator for $3 \mathrm{~h}$. Absorbance at $490 \mathrm{~nm}\left(\mathrm{OD}_{490}\right)$ was monitored with a spectrophotometer (SpectraMax M2, Molecular Devices Corp., operated by SoftmaxPro v.4.6 software, Sunnyvale, CA, USA) to obtain the number of surviving cells relative to control populations. The results are expressed as the median cytotoxic concentrations ( $\mathrm{IC}_{50}$ values) and were calculated from six-point dose response curves using 4-fold serial dilutions. Each point on the curve was tested in triplicate. Data are expressed as mean \pm SE for three replicates on each cell line.

\subsection{Antimicrobial assay}

The in vitro antimicrobial activity of the ligands and $\mathbf{3}$ and $\mathbf{4}$ was investigated as the minimum inhibitory concentration (MIC) against a number of Gram positive (Staphylococcus aureus, Bacillus cereus, Enterococcus faecalis) and Gram negative (Escherichia coli, Pseudomonas aeruginosa, Salmonella typhimurium bacteria strains. The bacteria were maintained on nutrient agar and cultured in Mueller Hinton Broth and compounds were dissolved in DMSO. The MIC was determined from a microdilution method. Approximately $30-\mathrm{mL}$ of bacteria culture was incubated overnight at $37.0^{\circ} \mathrm{C}$ to produce exponentially growing cells. This was then diluted to yield a suspension containing $1.5 \times 10^{8} \mathrm{CFU} / \mathrm{mL}$ (based on comparison of the turbidity to a $0.5 \mathrm{McFarland}$ standard). Subsequently, $250 \mu \mathrm{L}$ of this bacteria mixture were then inoculated into a sterile 96-well microplate. Various amounts of the compounds were added to wells to give predetermined concentrations ranging from 2 to $50 \mu \mathrm{M}$. The well absorbances (at $600 \mathrm{~nm}$ ) were recorded on a BioTek Synergy HT microplate reader immediately after inoculation. The microplates were incubated for $24 \mathrm{~h}$ at $37.0^{\circ} \mathrm{C}$, and then the absorbance recorded again after the $24 \mathrm{~h}$. The MIC was defined as the lowest concentration of compound that did not produce any visible cell-growth or change in absorbance after incubation. Solvent, media and positive growth controls were included on each plate. Ampicillin or streptomycin was used as a standard comparison. Each plate contained three replicates of each concentration and two separate experiments were done.

\section{Results and Discussion}

\subsection{Synthesis and Characterization}

The thiosemicarbazones used in this study are shown in Fig. 2. They were synthesized by the acid-catalyzed condensation of piperonal with the appropriately substituted $\mathrm{N}$-alkyl thiosemicarbazide in ethanol. The complexes (1-4) were synthesized from $[\mathrm{Ru}(p$ cymene) $\mathrm{Cl}_{2} \mathrm{I}_{2}$ by reaction with two equivalents of the thiosemicarbazone in $\mathrm{CH}_{2} \mathrm{Cl}_{2}$ at room temperature under argon. The yellow-orange solids that were obtained were very soluble in DMSO but less so in alcohols. Based on elemental analysis and spectroscopic data we propose that the complexes are best formulated as $\left[\left(\eta^{6}-p\right.\right.$ - cymene $\left.) \mathrm{Ru}(\mathrm{TSC}) \mathrm{Cl}\right] \mathrm{Cl}$ (Fig. 2). Although the analysis results for " $\mathrm{H}$ " (1) are somewhat unsatisfactory, the spectroscopic data (IR, ${ }^{1} \mathrm{H}$ and ${ }^{13} \mathrm{C}$ NMR) reasonably support the formula of the compound. [The complexes with pHTSC (1) and pMeTSC (2) as ligands were very difficult to handle. Detailed experiments were not performed using these complexes].

Thiosemicarbazone ligands can coordinate in a number of different ways. Most commonly they bind as either of two tautomeric forms - a neutral thione form or the anion from the thiol form. Infrared spectrophotometry was used to confirm coordination as the thione form. The ligands and complexes are very soluble in DMSO and so their NMR spectra were obtained in DMSO- $\mathrm{d}_{6}$. The ${ }^{1} \mathrm{H}$ NMR spectra of the ligands show similar patterns for the benzodioxole moiety differing only in the signals associated with the $\mathrm{N}_{b}-\mathrm{R}$ group. The $\mathrm{N}_{\mathrm{a}}-\mathrm{H}$ resonates as a sharp singlet at $11.32-11.38 \mathrm{ppm}$ (11.74 ppm for pPhTSC). For this ligand 
as well the $\mathrm{N}_{\mathrm{b}} \mathrm{H}$ proton is at $10.11 \mathrm{ppm}$ compared to $7.94-8.04 \mathrm{ppm}$ observed for the others. This shift downfield is possibly due to the proton locating in the cone of the phenyl ring or more likely to the electron density redistribution in the skeleton of the molecule. For pHTSC, the $\mathrm{N}_{\mathrm{b}} \mathrm{H}_{2}$ group generates two distinct singlets at 8.01 and $8.04 \mathrm{ppm}$. This pattern is to be expected as the protons are magnetically non-equivalent as a consequence of the $\mathrm{C}_{9}-\mathrm{N}_{\mathrm{b}}$ bond possessing some $\pi$ character via the mesomeric effect. This results in hindered rotation about this bond which is common in thioamides. The protons of the dioxole moiety show at $6.07 \mathrm{ppm}$. All the other protons resonate in regions commonly expected. In all cases for the ligands the absence of a signal at $\sim 4.00 \mathrm{ppm}$ that can be ascribed to $-\mathrm{SH}$ [26] is consistent with the idea that in solution, as in the solid state, the ligands exists as the thione tautomer.

The ${ }^{13} \mathrm{C}$ NMR spectra for the ligands are exactly as would be expected. Of special note is the high frequency signal near $180 \mathrm{ppm}$ which is due to the thioamide carbon, $\mathrm{C}_{9}$. There appears to be a general up-field shift of this resonance (in roughly $1 \mathrm{ppm}$ increments) as the $\mathrm{N}_{\mathrm{b}}-\mathrm{R}$ group changes from $\mathrm{H} \rightarrow \mathrm{CH}_{3} \rightarrow \mathrm{C}_{2} \mathrm{H}_{5} \rightarrow \mathrm{C}_{6} \mathrm{H}_{5}$. This might suggest that the $\mathrm{R}$ is affecting the electronic nature of the thioamide bond.

The $1 \mathrm{H}$ NMR and ${ }^{13} \mathrm{C}$ NMR spectra of the complexes are essentially a direct combination of the signals from the ligands plus those from the $p$-cymene moiety. In the ${ }^{1} \mathrm{H}$ NMR spectra all indications are that the ligands remain neutral (as evidenced by the presence of the $\mathrm{N}_{\mathrm{a}}-\mathrm{H}$ protons). None of the major indicator peaks of the ligands move significantly on complexation. The $\mathrm{N}_{\mathrm{a}}-\mathrm{H}$ signal along with the $\mathrm{N}_{\mathrm{b}}-\mathrm{H}$ and $\mathrm{C}_{8}-\mathrm{H}$ signal shift only slightly $(\sim \pm$ $0.03 \mathrm{ppm})$. The signals for the benzodioxole protons are just as unaffected by complexation. The $p$-cymene protons resonate at frequencies typically seen for this group [26]. A multiplet is seen near $5.80 \mathrm{ppm}$ attributed to the ring protons; the isopropyl methine is found near 2.80 $\mathrm{ppm}$ with the methyls occurring as a doublet at $1.20 \mathrm{ppm}$. The signal due to the methyl on the ring is observed at $2.10 \mathrm{ppm}$. A similar situation is observed from the ${ }^{13} \mathrm{C}$ spectra. The signals in the complexes attributed to the ligand are practically unchanged from the free ligands. This is somewhat unexpected especially for the $\mathrm{C}_{9}-\mathrm{S}$ and $\mathrm{C}_{8}-\mathrm{N}$ signals since they bind to the metal centre and changes in the electron density of these bonds might be expected.

The redox behaviour of complexes $\mathbf{3}$ and $\mathbf{4}$ has been studied by cyclic voltammetry in the positive region at a platinum disc electrode in $1.0 \mathrm{mM}$ solutions in dichloromethane containing $0.1 \mathrm{M}$ tetrabutylammonium hexafluorophosphate as the supporting electrolyte. Both complexes show two consecutive irreversible oxidations; the first at $+0.683 \mathrm{~V}$ for 3 and $+0.680 \mathrm{~V}$ for 4 , corresponding to the $\mathrm{Ru}(\mathrm{II}) / \mathrm{Ru}$ (III) couple. The second is an ill-defined oxidation wave at higher potential (near $1600 \mathrm{mV}$ vs. $\mathrm{Ag} / \mathrm{AgCl}$ ) that becomes slightly less defined as the scan rate is increased. Still the Ru-centred oxidation is irreversible even up to a scan rate of $500 \mathrm{mV} \mathrm{s}^{-1}$ (see Supplemental Information - Fig. S1).

The structure of $\mathbf{4}$ has been confirmed by X-ray methods. The crystal structure of [ $\left(\eta^{6}-\right.$ (cymene) $\mathrm{Ru}(\mathrm{pPhTSC}) \mathrm{Cl}]^{+}$is shown in Fig. 3. The crystallographic data, description and selected bond lengths and angles are given in Tables 1 and 2 . The complex adopts the archetypical piano-stool shape of Ru half-sandwich arene complexes. The metal centre has a slightly distorted octahedral geometry with bite angles around the ruthenium, involving the three legs of the piano stool, in the range $82^{\circ}-87^{\circ}$. This level of distortion is less than that seen in other structurally characterized Ru-arene thiosemicarbazone complexes [12]. The $\mathrm{Ru}-\mathrm{Cl}$ bond length of 2.4100(6) $\AA$ is in the same range as for similar complexes [12, 28] including those containing a $\pi$-acid with a nitrogen donor group [28]. The Ru-N(3), 2.1306(17) $\AA$, and Ru-S(1), 2.3492(6) $\AA$, along with the Ru-arene centroid distance of 1.699 $\AA$ are also essentially the same as we have observed for other Ru-arene thiosemicarbazone complexes [12]. As seen in those other complexes as well, the arene ring is oriented so as to 
possibly limit any steric interaction between the isopropyl group and the sulphur of the thiosemicarbazone ligand. The $\mathrm{C}(9)-\mathrm{S}(1)$ bond-length of 1.697(7) and the $\mathrm{C}(8)-\mathrm{N}(1)$ bondlength of 1.288(5) $\AA$ are typical of the $\mathrm{C}=\mathrm{S}$ and $\mathrm{C}=\mathrm{N}$ bonds found in free thiosemicarbazones and coordination complexes where the thione formed is coordinated, that we found trawling the literature.

\subsection{Interaction with DNA}

The mechanism of the biological action of half-sandwich Ru-arene complexes, $[(\operatorname{arene}) \mathrm{Ru}(\mathrm{LL}) \mathrm{Cl}]^{+}$, is being intensively studied $[3,4]$. It is believed that aquation of this complex generates a more reactive species towards DNA [29]. This binding may be facilitated by hydrophobic interactions with the arene while the ligand provides an additional site for binding. It has been established [3] that more hydrophobic arenes such as 5,8,9,10-tetrahydroanthracene and 9,10-dihydroanthracene (DHA) are stronger binders to DNA and are more cytotoxic compared to $p$-cymene. As it relates to the chelating ligand the structure-activity relationships for these complexes is somewhat complex. It was originally believed that a $\mathrm{NH}$ on the chelating ligand was required (based on the parent ethylenediamine complex for this class of compounds), but complexes with other ligands such as acetylacetonate (acac) or the monodentate phosphine 1,3,5-triaza-7phosphaadamantane (pta) [4] have shown good activity. Also when ethylenediamine is replaced by acac as the ligand the complex with $p$-cymene is more cytotoxic than that with the DHA [3]. It is also known that the ligand will also affect hydrolysis rates of the complexes. The design of our complexes was to facilitate this bifunctional mode of action that may include covalent binding to the nucleobases and non-covalent interactions such as groove binding or intercalation through the thiosemicarbazone ligand. The ligand has the piperonal moiety which contains the dioxole oxygens as well as $\mathrm{NH}$ groups that may participate in hydrogen bonding interactions with the DNA. We have studied the aquation reaction of $\mathbf{3}$ and $\mathbf{4}$. Concentrated solutions of the complexes in DMSO were diluted in aqueous buffer to a final concentration of $10 \mu \mathrm{M}$. The samples were analyzed by UV-Vis spectrophotometry, monitoring the absorbance changes of a broad band centred near $345 \mathrm{~nm}$ over $2 \mathrm{~h}$ at $298 \mathrm{~K}$ (see Fig. S2). This absorption of this band shifts to $332 \mathrm{~nm}$ and decreased as the reaction progressed. Further evolution of the spectrum over $24 \mathrm{~h}$ showed an increase in absorbance (no wavelength change) after $3 \mathrm{~h}$ but the spectrum after $24 \mathrm{~h}$ was not significantly different in shape and position form the spectrum after $2 \mathrm{~h}$. For compound $\mathbf{4}$ the band red shifts to about $354 \mathrm{~nm}$. The hydrolysis constant for 3 was calculated to be (1.4 \pm $0.3) \times 10^{-3} \mathrm{~s}^{-1}$ and $(6.6 \pm 1.8) \times 10^{-4} \mathrm{~s}^{-1}$ for 4 . By comparison for a similar compound, $\left[\left(\eta^{6}-p \text {-cymene }\right) \mathrm{Ru}(9 \text {-anthraldehyde-N(4)-ethylthiosemicarbazone }) \mathrm{Cl}\right]^{+}$, we calculated the rate of aquation to be $(1.2 \pm 0.2) \times 10^{-3} \mathrm{~s}^{-1}$ at an ionic strength of $50 \mathrm{mM} \mathrm{NaCl}$ at $298 \mathrm{~K}$. In addition other structurally similar complexes, $\left[\left(\eta^{6}-p-\mathrm{X}\right) \mathrm{Ru}(\mathrm{en}) \mathrm{Cl}\right]\left[\mathrm{PF}_{6}\right]$, where $\mathrm{X}=$ biphenyl, 5,8,9,10-tetrahydroanthracene, and 9,10-dihydroanthracene and en $=$ ethylenediamine, have been reported to have aquation rates of $1.23-2.59 \times 10^{-3} \mathrm{~s}^{-1}$ at 298 $\mathrm{K}$ and $100 \mathrm{mM}$ ionic strength [30]. While the exact nature of the hydrolysis product is unknown (as the kinetic traces indicate further transformation after about $2 \frac{1}{2} \mathrm{~h}$ ), it is reasonable to propose that the complexes possess the ability to aquate and bind DNA via a covalent bond. Further studies using model nucleobases may illuminate this issue.

3.2.1 Ethidium bromide competition experiments-To investigate other possible modes of binding with DNA, we have carried out a competition experiment with EB. The complexes do not show any appreciable emission in DMSO and also lack emission in buffer even in the presence of DNA. The experiment with EB is based on the ability of the metal complex to quench, even partially, the fluorescence of the complex formed between the EB and DNA. EB is a known intercalator into DNA and reduction of the fluorescence of this complex in the presence of the metal complexes may be interpreted as being due to 
replacement of some of the EB molecules by the complexes. Implicit here is the idea that the complexes may intercalate into DNA. It is also true however that the reduction in fluorescence may be due to a direct quenching on the DNA itself. Figure 4 and Figure 5 show the moderate decrease $(\sim 35 \%)$ in fluorescence when EB-DNA is titrated with $\mathbf{3}$ and $\mathbf{4}$. The extent of the fluorescence quenching can be used to determine the extent of the interaction with the complexes.

In order to quantitatively assess the magnitude of this interaction between the complexes and DNA, the Stern-Volmer equation is used:

$$
\frac{F_{0}}{F}=1+K_{S V}[R u]
$$

$\mathrm{F}$ and $\mathrm{F}_{0}$ are the fluorescence intensities of the DNA solution in the presence and absence of the complexes, $\mathrm{K}_{\mathrm{SV}}$ is the Stern-Volmer quenching constant and [Ru] is the concentration of the metal complexes. The insets of Fig. 4 and Fig. 5 are the Stern-Volmer plots and the good linearity of the plots suggests a singular mode of quenching. The values for the $\mathrm{K}_{\mathrm{SV}}$ are given in Table 3. These values are on the order of $10^{3}$ to $10^{4} \mathrm{M}^{-1}$ which makes the complexes weak intercalators. The apparent binding constant for complexes was calculated using the equation: $\mathrm{K}_{\mathrm{app}}=\mathrm{K}_{\mathrm{EB}}[\mathrm{EB}] /[\mathrm{Ru}]_{50 \%}$ where $\mathrm{K}_{\mathrm{EB}}=1.2 \times 10^{6} \mathrm{M}^{-1}$ [31]. $\mathrm{K}_{\mathrm{EB}}$ is the binding constant of EB to DNA and $[\mathrm{Ru}]_{50 \%}$ is the concentration of $\mathbf{3}$ and $\mathbf{4}$ at $50 \%$ of the initial fluorescence. These $\mathrm{K}_{\text {app }}$ values are also given in Table 3 and are on the same order of magnitude as the $\mathrm{K}_{\mathrm{SV}}$ values.

We carried out a similar competition experiment using Hoechst 33258. This dye binds to BDNA in two concentration dependent ways. The first type of binding occurs in the minor groove at low dye-to-DNA ratios [32,33]. The fluorescence yield of Hoechst 33258 increases significantly in presence of DNA [34]. The displacement of bound Hoechst 33258 from its binding site on ct-DNA is implicated from a decrease in its fluorescence intensity on addition of the complexes. When the complexes are added to Hoechst-DNA solution we observed a decrease (34\% for $\mathbf{3}$ and 50\% for $\mathbf{4}$ ) in the fluorescence (see Fig. S3 and S4). This suggests that the complexes are capable of binding in the minor groove of DNA.

3.2.2 Viscometric studies-Among the most common methods used to investigate the possibility of an intercalative mechanism, hydrodynamic measurements (viscometry in particular) that are sensitive to DNA length changes are the most definitive. A classical intercalator will cause an increase in the viscosity of a DNA solution since the DNA helix must lengthen as base pairs are separated to accommodate the binding ligand [35]. On the other hand, complexes that bind exclusively in the DNA grooves by a partial or nonclassical intercalation of the compound, (under the same conditions), can reduce its effective length, and concomitantly, its viscosity by bending the DNA helix [36]. The viscometric experiments involve measuring the viscosity of ct-DNA solutions $(100 \mu \mathrm{M})$ containing various amounts of 3 or $4(0-60 \mu \mathrm{M})$. The data were treated by plotting $\left(\eta / \eta_{0}\right)^{1 / 3} v s$. the binding ratio $[\mathrm{Ru}] /[\mathrm{DNA}]$. (See Fig. S5). It was observed that increasing the concentration of $\mathbf{3}$ or $\mathbf{4}$ led to an increase in the viscosity of the DNA solution followed by a decrease at higher concentrations. From this figure we can suggest that the interaction with DNA is somewhat non-specific and the complexes are weak intercalators.

3.2.3 Cleavage of plasmid DNA-The chemical nuclease activity of complexes $\mathbf{3}$ and $\mathbf{4}$ has been assessed by their ability to convert supercoiled pBR322 DNA from Form I to Form II by agarose gel electrophoresis in the dark as well as under UV irradiation under aerobic conditions. When circular plasmid DNA is probed by electrophoresis, relatively fast 
migration is normally observed for the intact supercoil form (Form I). If scission occurs on one strand (nicking), the supercoil will relax to generate a slower-moving open circular form (Form II). In the dark or following irradiation with UV light the complexes show no significant cleavage of the DNA but there is a slight increase in this activity as the concentration of the complexes increased (up to $300 \mathrm{uM}$ ) (see Fig. S6). We also studied the reaction in the presence of hydroxyl scavengers HCOONa and $\mathrm{KI}$ as well as the singlet oxygen-like species scavenger $\mathrm{NaN}_{3}$. These species seem capable of inhibiting the marginal nuclease activity of the complexes with sodium azide appearing to be the strongest inhibitor. This would seem to imply the role of reactive-oxygen species in the interaction of the complexes with DNA.

\subsection{Topoisomerase inhibition}

Topoisomerases are a class of ubiquitous enzymes that modulate the topological problems associated with DNA replication, transcription, and other nuclear processes by introducing transient single- (type I topoisomerase) or double-strand (type II topoisomerase) breaks in the DNA. Without topoisomerases, the DNA cannot replicate normally and topo II is a major enzyme in neoplastic cells. So although DNA is implicated as the main target for anticancer ruthenium compounds, affecting the activity of topo II may also be an effective mode of antineoplastic activity. Topoisomerase inhibitors are substances that interfere with the normal functioning of topoisomerase enzymes. These inhibitors are split into two main classes: topoisomerase poisons, which target the topoisomerase-DNA complex, and topoisomerase inhibitors which disrupt the enzyme's catalytic cycle. The ability of complexes $\mathbf{3}$ and $\mathbf{4}$ to affect the catalytic activity of human topoisomerases II was studied by a DNA relaxation assay. Supercoiled plasmid DNA was treated with topo II in the presence of varying concentrations of the complexes and the products were analysed by agarose gel electrophoresis. Depending on the nature of the products one can propose if the complex is a poison or an inhibitor. Fig. 6 shows the gel electrophoretic diagram for the concentrationdependent experiment. Enzyme activity is characterized by conversion of pHOT1 DNA from the supercoiled conformation (I) to the fully relaxed conformation (II). The species migrating between the two forms (lane 3) are the various topoisomers indicating that the enzyme was causing relaxation. From the figure it is clear that both complexes can prevent the relaxation by the enzyme (to almost the same extent) at concentrations as low as $20 \mu \mathrm{M}$ (lanes 4-7) as evidenced by the absence of the topoisomers and the presence of mainly the supercoiled form of the DNA. So we propose that the complexes can act as strong catalytic inhibitors. There was no formation of linear DNA, which would be evidence for the formation of an enzyme-drug-DNA ternary complex, during the reaction which supports the preceding conclusion. Previously, moderate to strong anti-topoisomerase activity by areneruthenium complexes of the type [(benzene $) \mathrm{Ru}(\mathrm{DMSO}) \mathrm{Cl}_{2}$ ] and [(benzene $\left.) \mathrm{Ru}(\mathrm{L}) \mathrm{Cl}_{2}\right](\mathrm{L}=$ pyridine, 3-aminopyridine, $p$-aminobenzoic acid, and aminoguanidine) was reported [37, 38]. Those complexes were observed to inhibit relaxation as well as promote formation of the cleavage complex or cross-linking with topoisomerase. We have also notice in our research that complexes like 3 and $\mathbf{4}\left([(\text { cymene }) \mathrm{Ru}(\mathrm{TSC}) \mathrm{Cl}]^{+}\right)$, can inhibit topo II to varying degrees (F. Beckford, V. Crowell, P.C. Mbarushimana, unpublished work).

\subsection{Interaction with human serum albumin}

3.4.1 Fluorescence titration-As the principal extracellular protein of the circulatory system, HSA serves as the major transporter of drugs as well as endogenous compounds such as fatty acids since these compounds can bind reversibly to the HSA. It has been shown that the distribution, free concentration and the metabolism of various drugs can be significantly altered as a result of their binding to HSA. HSA also often increases the apparent solubility of hydrophobic drugs in plasma. Since HSA serves as a transport carrier for drugs, it is important to study the interactions of potential drugs with this protein. 
Knowledge of interaction mechanisms between drugs and plasma proteins is of crucial importance to the understanding of the pharmacodynamics and pharmacokinetics of a drug or drug prospect. Fluorescence spectrophotometry is a powerful method to study molecular interaction with proteins. We have studied the interaction of $\mathbf{3}$ and $\mathbf{4}$ with HSA by emissionquenching experiments. HSA contains 585 amino acid residues with a single tryptophan located at position 214. Tryptophan fluorescence is the most frequently studied among the three fluorescent groups in HSA. By measuring the intrinsic fluorescence quenching of HSA, the accessibility of quenchers to the tryptophan residue can be estimated. When HSA is excited at $295 \mathrm{~nm}$, changes in a fluorescence emission near $350 \mathrm{~nm}$ reflect modification in the micro-environment of the tryptophan residue. It can be observed from Fig. 7 and Fig. 8 that titration of HSA with the metal complexes led to dramatic decreases in the HSA fluorescence ( $80 \%$ of the initial fluorescence for $\mathbf{3}$ and $90 \%$ for $\mathbf{4}$ ) suggesting that binding occurs at or near the tryptophan residue causing changes in the secondary structure of the protein. It can also be observed that there is a blue shift of about $17 \mathrm{~nm}$ to near $330 \mathrm{~nm}$. It seems likely that binding results in reduction of the tryptophan exposure to a polar environment. Emission in this region suggests that the tryptophan residue is buried in a nonpolar hydrophobic pocket on the HSA.

The insets of Fig. 7 and Fig. 8 shows the Stern-Volmer plot which is expected to be a straight line. However it is obvious that there are strong positive deviations in the plots. The concave-up nature of these plots usually indicates that both dynamic and static quenching is involved. Under these circumstances the Stern-Volmer equation may be written as equation 2 [39].

$$
K_{\text {app }}=\left(\frac{F_{0}}{F}-1\right) \cdot \frac{1}{[R u]}=\left(K_{D}+K_{S}\right)+K_{D} K_{S}[R u]
$$

A plot of $\mathrm{K}_{\mathrm{app}} v s$. [Ru] should give a linear plot with $\left(\mathrm{K}_{\mathrm{S}}+\mathrm{K}_{\mathrm{D}}\right)$ as the intercept and $\mathrm{K}_{\mathrm{D}} \mathrm{K}_{\mathrm{S}}$ as the slope. $\mathrm{K}_{\mathrm{S}}$ and $\mathrm{K}_{\mathrm{D}}$ are the quenching contributions from the static and dynamic mechanisms respectively. In our analysis we were unable to separate the two contributions as imaginary numbers resulted from solving the equation. [Another way to estimate qualitatively the type of mechanism present is to consider the effect of temperature on the system]. We can therefore assume that both mechanisms play a significant role in the quenching. Under these circumstances the fluorescence data may be treated with a modified version of the Stern-Volmer equation:

$$
\frac{F_{0}}{F}=\frac{1}{f K[R u]}+\frac{1}{f}
$$

This allows estimation of the apparent binding constant $\mathrm{K}$ for the process from the ratio of the slope to intercept of a plot of $\mathrm{F}_{0} / \mathrm{F} v s .1 /[\mathrm{Ru}]$. (See Fig. S7). This plot is given in Figure 11. The calculated binding constants (Table 4 ) show that complex $\mathbf{4}$ interact stronger than $\mathbf{3}$, $10^{5} v s .10^{4} \mathrm{M}^{-1}$. The thermodynamic parameters $(\Delta \mathrm{H}$ and $\Delta \mathrm{S})$ derived from the van't Hoff equation are also given in Table 4 and may be used to suggest the binding mode. The various forces of attraction between the complexes and the HSA include hydrogen bond formation, electrostatic forces, van der Waals forces and hydrophobic interactions. According to Ross and Subramanian [40] when $\Delta \mathrm{H}>0$ and $\Delta \mathrm{S}>0$, the situation observed in our cases, hydrophobic interactions are implicated as the major binding mode. We can infer from the small positive $\Delta \mathrm{H}$ of $5.43 \mathrm{~kJ} / \mathrm{mol}$ for $\mathbf{4}$ that electrostatic binding also plays a part. Typically for electrostatic interactions $\Delta \mathrm{H}$ is zero or a small positive value [40]. This might explain the much higher binding constants for this complex. There is not much literature 
precedent for complexes like $\mathbf{3}$ and $\mathbf{4}$ interacting with HSA, but it is possible that covalent binding to the ruthenium center does occur. It is known that DNA binds very strongly (through a guanine residue) to such complexes with the aid of hydrophobic forces [41]. A similar reaction with HSA through the indole ring on the tryptophan would be weak however as it would require deprotonation of the indole nitrogen. By analogy with the purine bases of DNA, this is less probable under physiological pHs. Still, with the data at hand it is not clear that we can quantitatively separate out the contribution of any covalent interaction. Nonetheless this idea is part of the design strategy of this class of anticancer compounds: the incorporation of features that enhance simultaneous hydrophobic and covalent coordination in order to optimize biological targeting. The binding process is always spontaneous as implied by the negative value of $\Delta \mathrm{G}^{\circ}$. It can also be suggested that the entropic term provides the major contribution to the free energy.

3.4.2 Infrared spectrophotometry-The infrared spectra of proteins exhibit the amide I bond (due to the stretching of the $\mathrm{C}=\mathrm{O}$ functional group of the peptide moiety) between 1600 and $1700 \mathrm{~cm}^{-1}$. The exact position is determined by the backbone conformation. Since this band is associated with the secondary structure of the protein [42] perturbations of the bond on interaction with the metal compounds can provide a qualitative assessment of the binding assuming that the binding induces a conformation change. Infrared spectroanalysis of a solution of HSA before and after incubation with $\mathbf{3}$ and $\mathbf{4}$, show that the amide I band shift only slightly ' 1638.23 to $1638.72 \mathrm{~cm}^{-1}$ for 3 and 1638.73 to $1639.68 \mathrm{~cm}^{-1}$ for 4 (see Fig. S8). Though other reasons are possible, this indicates that the secondary structure of HSA is perturbed though not dramatically so. It also confirms that $\mathbf{4}$ interact stronger with HSA.

\subsection{Biological Activity}

3.5.1 Cytotoxicity assay-The in vitro cytotoxicity of complexes 3 and $\mathbf{4}$ against two human cancer cell lines, HCT-116 (colon carcinoma) and Caco-2 (epithelial colorectal adenocarcinoma) and a non-cancerous cell line, CCD-18Co (colon fibroblasts) was investigated using a tetrazolium-based (MTS) colorimetric assay. Etoposide, a potent antineoplastic drug, and cisplatin, a platinum-based chemotherapy drug, were used as a standard comparison treatment. The $\mathrm{IC}_{50}$ values, the median cytotoxic concentrations, were determined after 24,48 and $72 \mathrm{~h}$ of drug exposure. Generally, the longer the exposure time the more cytotoxic is the complexes with the $72 \mathrm{~h}$ exposure being between 1.3 and 2 times more effective compared to the $24 \mathrm{~h}$ exposure. As another generality, the Caco- 2 cell line is more sensitive to the complexes than the HCT-116 cell line. For instance at $72 \mathrm{~h}$ exposure, 3 is twice as cytotoxic against the Caco-2 line. Furthermore $\mathbf{3}$ is more active than $\mathbf{4}$ against Caco-2 and HCT-116 ( $\mathrm{IC}_{50}=26.3$ to 121 and 50.5 to $153 \mu \mathrm{M}$, respectively), Table 5). Given that $\mathbf{4}$ has a stronger binding to DNA, we speculate that DNA interaction may not be the primary reason for the cytotoxic behaviour. From a simple structure-activity analysis (see Table S1) we can also speculate that the alkyl group on the thiosemicarbazone moiety is probably non-innocent as there are distinct differences in the cytotoxic behaviour as that group is varied.

As a point of interest, it was observed that the cytotoxic effect on the non-cancerous cell line is noticeably less than on the two cancer lines. The small effect is true even for the standard drug treatment with etoposide being about $\sim 2.5$ times more lethal to the cancer cells versus the non-cancerous cells. The $\mathrm{IC}_{50}$ values for the complexes are in the micromolar range indicating the good to moderate cytotoxicity of the complexes, being about $\sim 2.5$ and $\sim 1.3$ times as active against HCT-116 and HT-29, respectively (Table 5). Finally, under the experimental conditions 3 shows comparable activity to etoposide and cisplatin ( $26.3 \mu \mathrm{M}$ to 
$16.5 \mu \mathrm{M}$ and $14.9 \mu \mathrm{M}$, respectively) against Caco-2. On the other hand, $\mathrm{IC}_{50}$ values after treatment with 4 show higher differences (Table 5).

In general however the complexes do not reach the activity of the standard against the cancer cell lines. This is in itself not an unusual issue. It is known that some ruthenium arene complexes have low in vitro toxicity but show good in vivo anti-metastatic characteristics. For example, complexes of the type $\left[\left(\eta^{6}\right.\right.$-cymene $\left.) \mathrm{Ru}(\mathrm{PTA}) \mathrm{Cl}\right]+$ exhibited low activity against cancer cells but had very good antimetastatic activity in vivo [4].

3.5.2 Antimicrobial Studies-The in vitro antimicrobial efficiency of the ligands and the complexes $\mathbf{3}$ and $\mathbf{4}$ against a number of Gram-positive and Gram-negative bacteria has been determined as the minimum inhibitory concentrations (see Table S2). The compounds were tested at low concentrations due to solubility issues and to avoid excessive concentrations of the solvent DMSO in the wells. The complexes were more active against the Gram-positive bacteria than the Gram-negative species showing moderate activity against Bacillus cereus and Staphylococcus aureus. In general $\mathbf{4}$ is more active than $\mathbf{3}$ for bacteria for which an $\mathrm{IC}_{50}$ value was determined. For instance the $\mathrm{IC}_{50}$ for $\mathbf{4}$ against Staphylococcus aureus is $30 \mu \mathrm{M}$ and for 3 it was $50 \mu \mathrm{M}$. The complexes were also found to be more active than the free ligand. This is not unusual because as mentioned before it is known that complexation to a metal ion may induce improved biological activity and in some cases even different biological activity [16-18, 43]. Such complexation could enhance the lipophilic character of the compound which favours its permeation through the lipid layers of cell membrane. Although the complex is active, at least against certain species, it typically did not achieve the effectiveness of the conventional antibacterial standards ampicillin or streptomycin.

\section{Conclusions}

We have prepared a series of new ruthenium-arene piano-stool complexes with thiosemicarbazones as the coordinating ligand. The compounds show in vitro activity as anticancer agents against human colon cancer cells. DNA has been postulated as a primary target for organometallic ruthenium anticancer compounds and the studied compounds interact with moderately with DNA though we cannot conclusively say in what manner. They can also inhibit the activity of human topo II and it is clear that this enzyme may therefore be an important target for these types of compounds. With respect to the modest anticancer behaviour, the compounds are not dissimilar from other ruthenium arene complexes under active investigation and these complexes may still have the potential for drug development.

\section{Supplementary Material}

Refer to Web version on PubMed Central for supplementary material.

\section{Abbreviations}

$\begin{array}{ll}\text { HSA } & \text { human serum albumin } \\ \text { TSC } & \text { thiosemicarbazone } \\ \text { CFU } & \text { colony forming units } \\ \text { EMEM } & \text { Eagles minimum essential medium } \\ \text { Topo II } & \text { topoisomerase II } \\ \text { PDL } & \text { population double level }\end{array}$


EB ethidium bromide

SERM selective estrogen receptor modulators

ER estrogen receptor

MSV modified Stern-Volmer

\section{Acknowledgments}

The project described was supported by Award Number P20RR16460 from the National Centre for Research Resources to FAB. The content is solely the responsibility of the authors and does not necessarily represent official views of the National Centre for Research Resources or the National Institutes of Health.

\section{Appendix A. Supplementary material}

CCDC 798099 contains supplementary crystallographic data for 4 . These data can be obtained free of charge from the Cambridge Crystallographic Data Centre via http://www.ccdc.com.ac.uk/data_request/cif

\section{References}

1. Top S, Kaloun EB, Vessières A, Laïos I, Leclercq G, Jaouen G. J. Organomet. Chem. 2002; 643644:350-356.

2. Popova LV, Babin VN, Belousov YA, Nekrasov YS, Snegireva AE, Borodina NP, Shaposhnikova GM, Bychenko OB, Raevskii PM. Appl. Organomet. Chem. 1993; 7:85-94. 7.

3. Morris RE, Aird RE, del P, Murdoch S, Chen H, Cummings J, Hughes ND, Parsons S, Parkin A, Boyd G, Jodrell DI, Sadler PJ. J. Med. Chem. 2001; 44:3616-3621. [PubMed: 11606126]

4. Scolaro C, Bergamo A, Brescacin L, Delfino R, Cocchietto M, Laurenczy G, Geldbach TJ, Sava G, Dyson PJ. J Med Chem. 2005; 48:4161-4171. [PubMed: 15943488]

5. Jaouen, G.; Top, S.; Raynaud, JP., inventors. French Patent. 2725720-AI. 1994.

6. Top S, Tang J, Vessières A, Carrez D, Provot C, Jaouen G. Chem. Commun. 1996:955-956.

7. Top S, Vessières A, Leclercq G, Quivy J, Tang J, Vaissermann J, Huché M, Jaouen G. Chem. Eur. J. 2003; 9:5223-5236.

8. Jaouen G, Top S, Vessières A, Leclercq G, McGlinchey MJ. Curr. Med. Chem. 2004; 11:25052517. [PubMed: 15379709]

9. Delhaes L, Abessolo H, Biot C, Berry L, Delcourt P, Maciejewski LA, Brocard JS, Camus D, Dive D. Parasitol. Res. 2001; 87:239-244. [PubMed: 11293573]

10. Biot C, Glorian G, Maciejewski LA, Brocard JS. J. Med. Chem. 1997; 40:3715-3718. [PubMed: 9371235]

11. Allardyce CS, Dorcier A, Scolaro C, Dyson PJ. Appl.Organomet. Chem. 2005; 19:1-10.

12. Beckford FA, Leblanc G, Thessing J, Shaloski M Jr, Frost BJ, Li L, Seeram NP. Inorg. Chem. Commun. 2009; 12:1094-1098. [PubMed: 20160909]

13. Quiroga AG, Perez JM, Lopez-Solera I, Masaguer JR, Luque A, Raman P, Edwards A, Alonso C, Navarro-Ranninger C. J. Med. Chem. 1998; 41:1399-1408. [PubMed: 9554873]

14. Offiong OE, Martelli S. Farmaco. 1994; 49:513-518. [PubMed: 7945719]

15. Hadjipavlou-Litina D. Pharmazie. 1996; 51:468-470. [PubMed: 8774839]

16. Garcia-Tojal J, Garcia-Orad A, Serra JL, Pizarro JL, Lezamma L, Arriortua MI, Rojo T. J. Inorg. Biochem. 1999; 75:45-54. [PubMed: 10402676]

17. Petering DH. Bioinorg. Chem. 1972; 1:255-271.

18. West DX, Liberta AE, Padhye SB, Chikate RC, Sonawane PB, Kumbhar AS, Yerande RG. Coord. Chem. Rev. 1993; 123:49-71.

19. Bennett MA, Smith AK. Dalton Trans. 1974:233-241. 
20. Sheldrick GM. Acta Cryst. 2008; A64:112-122. G.M. Sheldrick, SHELXTL: Structure Determination Software Suite, Version 6.10; Bruker AXS: Madison WI, 2001.

21. Reichmann ME, Rice SA, Thomas CA, Doty PJ. J. Am. Chem. Soc. 1954; 76:3047-3053.

22. Vijayalakshmi R, Kanthimathi M, Subramanian V, Nair BU. Biochim. Biophys. Acta. 2000; 1475:157-162. [PubMed: 10832030]

23. Barton JK, Goldberg JM, Kumar CV, Turro NJ. J. Am. Chem. Soc. 1986; 108:2081-2088.

24. Krimm S, Bandekar J. Adv. Protein Chem. 1986; 38:181-364. [PubMed: 3541539]

25. Cory AH, Owen TC, Barltrop JA, Cory JG. Cancer Commun. 1991; 3:207-212. [PubMed: 1867954]

26. Singh S, Athar F, Azam A. Biorg. \& Med. Chem. Lett. 2005; 15:5424-5428.

27. Das S, Sinha S, Britto R, Somasundaram K, Samuelson AG. J. Inorg. Biochem. 2010; 104 93-10.

28. Bugarcic T, Habtemariam A, Stepankova J, Heringova P, Kasparkova J, Deeth RJ, Johnstone RDL, Prescimone A, Parkin A, Parsons S, Brabec V, Sadler PJ. Inorg Chem. 2008; 47:11470-11486. [PubMed: 19007206]

29. Chen H, Parkinson JA, Morris RE, Sadler PJ. J. Am. Chem. Soc. 2003; 125:173-186. [PubMed: 12515520]

30. Wang F, Chen H, Parsons S, Oswald JDH, Davidson JE, Sadler PJ. Chem. Eur. J. 2003; 9:58105820.

31. Peberdy JP, Malina J, Khalid S, Haman MJ, Rodger A. J. Inorg. Biochem. 2007; 101:1937-1945. [PubMed: 17719088]

32. Pjura PE, Grzeskowiak K, Dickerson RE. J. Mol. Biol. 1987; 197:257-271. [PubMed: 2445998]

33. Guan Y, Shi R, Li X, Zhao M, Li Y. J. Phys. Chem. B. 2007; 111:7336-7344. [PubMed: 17530793]

34. Weisblum B, Haenssler E. Choromosoma. 1974; 46:255-271.

35. Long EC, Barton JK. Acc. Chem. Res. 1990; 23:271-273.

36. Satyanarayana S, Dabrowiak JC, Chaires JB. Biochemistry. 1992; 31:9319-9324. [PubMed: 1390718]

37. Vashisht Gopal YN, Jayaraju D, Kondapi AK. Biochemistry. 1999; 38:4382-4388. [PubMed: 10194357]

38. Vashisht Gopal YN, Konuru N, Kondapi AK. Arch. Biochem. Biphys. 2002; 401:53-62.

39. Zhao J, Nelson DJ. J. Inorg. Biochem. 2005; 99:383-396. [PubMed: 15621270]

40. Ross PD, Subramanian S. Biochemistry. 1981; 20:3096-3102. [PubMed: 7248271]

41. Novakova O, Chen H, Vrana O, Rodger A, Sadler PJ, Brabec V. Biochemistry. 2003; 42:1154411554. [PubMed: 14516206]

42. Byler DM, Susi H. Biopolymers. 1986; 25:469-487. [PubMed: 3697478]

43. Lobana TS, Sharma R, Bawa G, Khanna S. Coord. Chem. Rev. 2008; 253:977-1055.

J Inorg Biochem. Author manuscript; available in PMC 2012 August 1. 


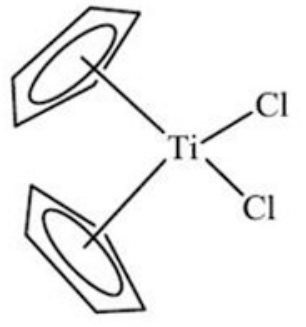

I

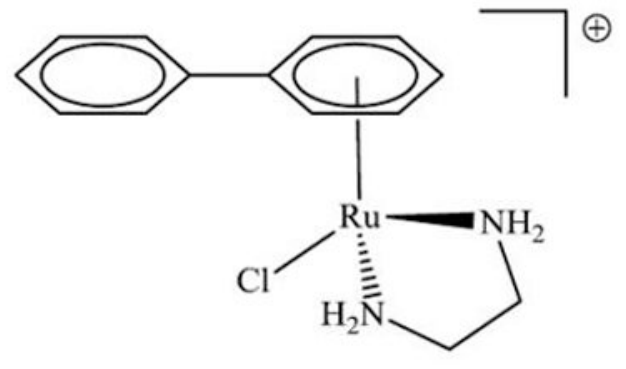

II - RM175

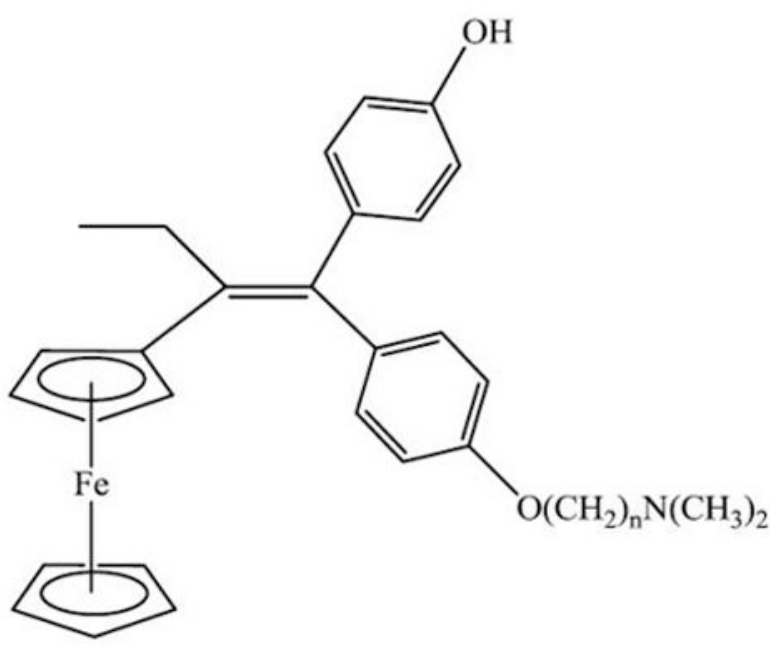

IV $(n=2-5)$

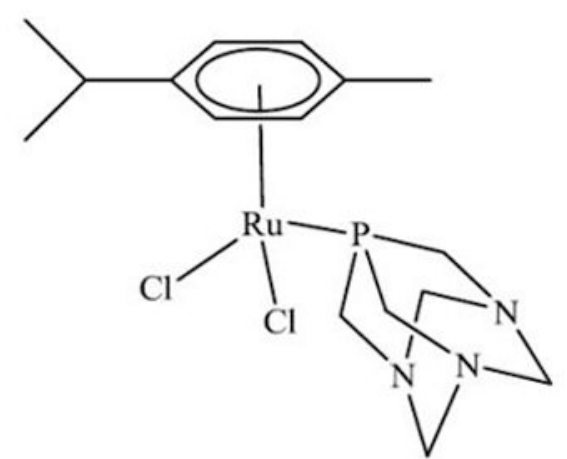

III

Figure 1.

Antitumor organometallic complexes 
<smiles>NC(=S)N/N=C/c1ccc2c(c1)OCO2</smiles><smiles>S=C(N/N=C/c1ccc2c(c1)OCO2)Nc1ccccc1</smiles>
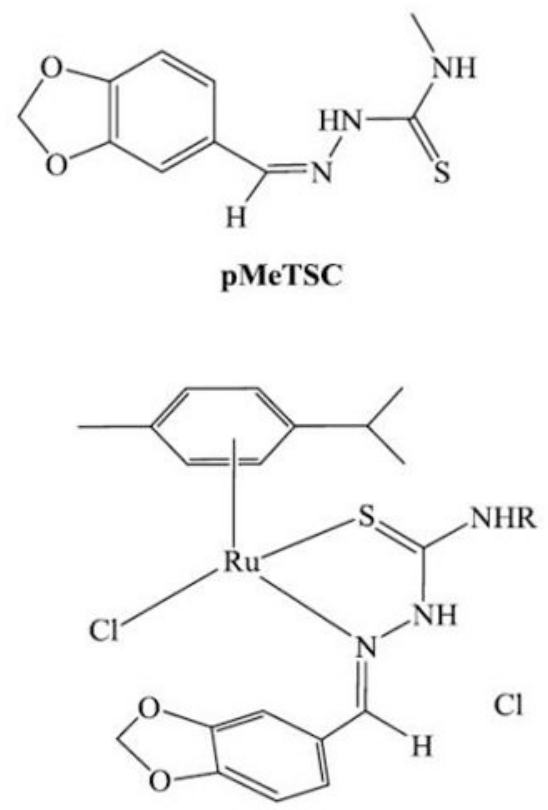

1: $\mathrm{R}=\mathrm{H} ; 2: \mathrm{R}=\mathrm{CH}_{3} ; 3: \mathrm{R}=\mathrm{C}_{2} \mathrm{H}_{5} ; 4: \mathrm{R}=\mathrm{C}_{6} \mathrm{H}_{5}$

Figure 2.

Structure of the ligands (including a labeling scheme) and complexes used in this study<smiles>CCNC(=S)N/N=C/c1ccc2c(c1)OCO2</smiles>

pEtTSC<smiles></smiles> 


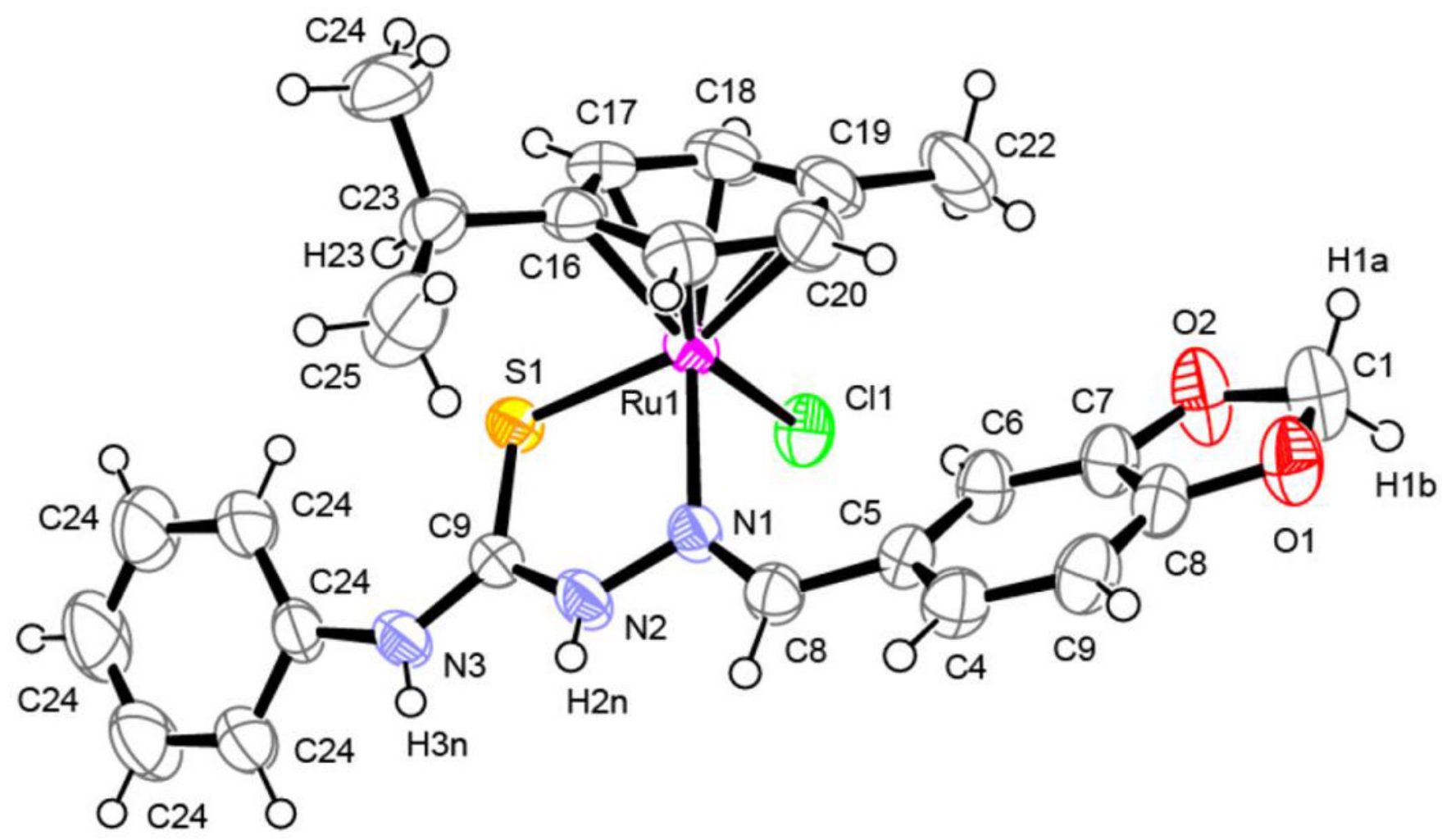

Figure 3.

An OPTEP drawing at 50\% thermal ellipsoids probability. A perspective view of the molecular structure and numbering scheme for the $\left[\eta^{6} p \text {-cymene)Ru(pPhTSC)Cl }\right]^{+}$cation (4). The label for hydrogen atoms, the chloride counter-anion and disordered molecule of dichloromethane are not shown for clarity. 


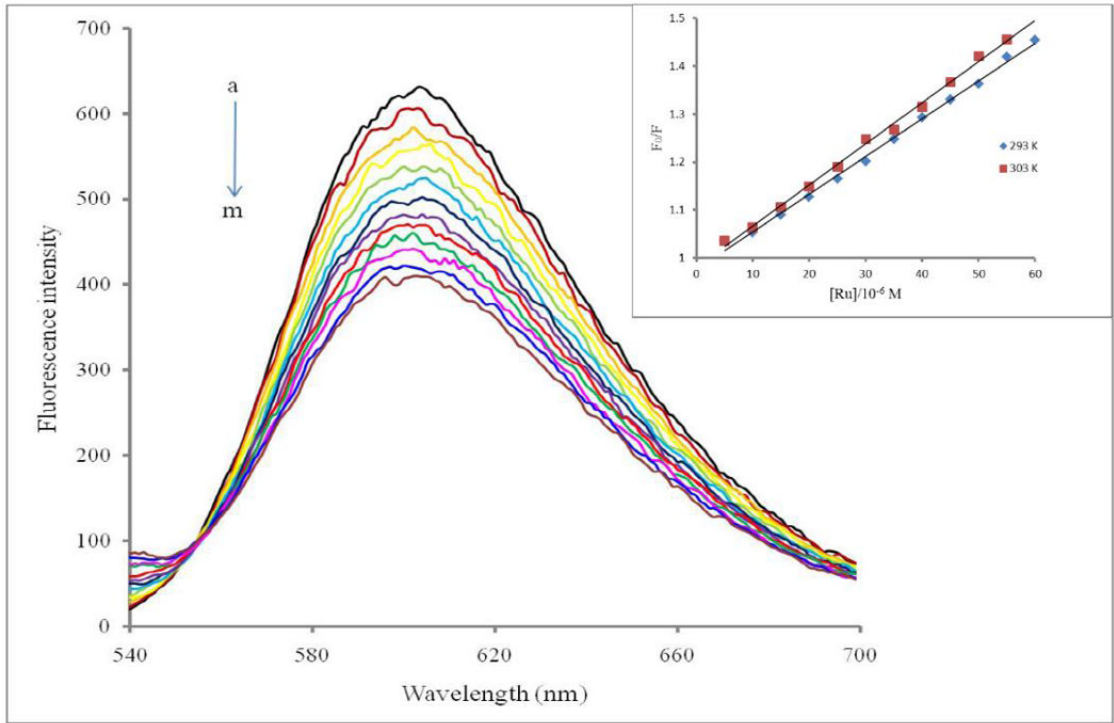

Figure 4.

Fluorescence spectra of EB-bound ct-DNA in aqueous buffer in the presence of increasing amounts of $\mathbf{3}$, at $303 \mathrm{~K} . \lambda_{\mathrm{ex}}=520 \mathrm{~nm},[\mathrm{~EB}]$ and [DNA] are $0.33 \mu \mathrm{M}$ and $10 \mu \mathrm{M}$ respectively. [3] = (a) $0 \mu \mathrm{M}$, (b) $10 \mu \mathrm{M}$, (c) $10 \mu \mathrm{M}$, (d) $15 \mu \mathrm{M}$, (e) $20 \mu \mathrm{M}$, (f) $25 \mu \mathrm{M}$, (g) $30 \mu \mathrm{M}$, (h) 35 $\mu \mathrm{M}$, (i) $40 \mu \mathrm{M}$, (j) $45 \mu \mathrm{M}$, (k) $50 \mu \mathrm{M}$, (l) $55 \mu \mathrm{M}$, (m) $60 \mu \mathrm{M}$. Inset: Stern-Volmer plots 


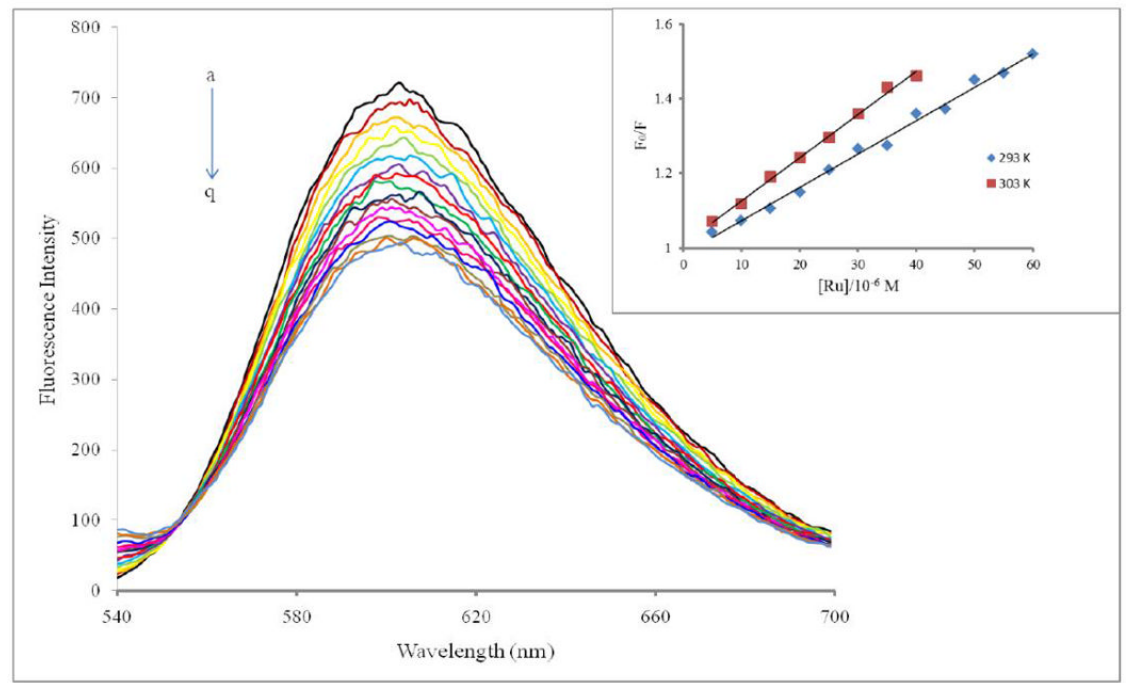

Figure 5.

Fluorescence spectra of EB-bound ct-DNA in aqueous buffer in the presence of increasing amounts of 4 , at $303 \mathrm{~K} . \lambda_{\mathrm{ex}}=520 \mathrm{~nm},[\mathrm{~EB}]$ and [DNA] are $0.33 \mu \mathrm{M}$ and $10 \mu \mathrm{M}$ respectively. [4] = (a) $0 \mu \mathrm{M}$, (b) $2.5 \mu \mathrm{M}$, (c) $5.0 \mu \mathrm{M}$, (d) $7.5 \mu \mathrm{M}$, (e) $10 \mu \mathrm{M}$, (f) $12.5 \mu \mathrm{M}$, (g) $15 \mu \mathrm{M}$, (h) $17.5 \mu \mathrm{M}$, (i) $20 \mu \mathrm{M}$, (j) $22.5 \mu \mathrm{M}$, (k) $25 \mu \mathrm{M}$, (l) $27.5 \mu \mathrm{M}$, (m) $30 \mu \mathrm{M}$ (n) $32.5 \mu \mathrm{M}$, (o) 35 $\mu \mathrm{M}$, (p) $37.5 \mu \mathrm{M}$, (q) $40 \mu \mathrm{M}$. Inset: Stern-Volmer plots 


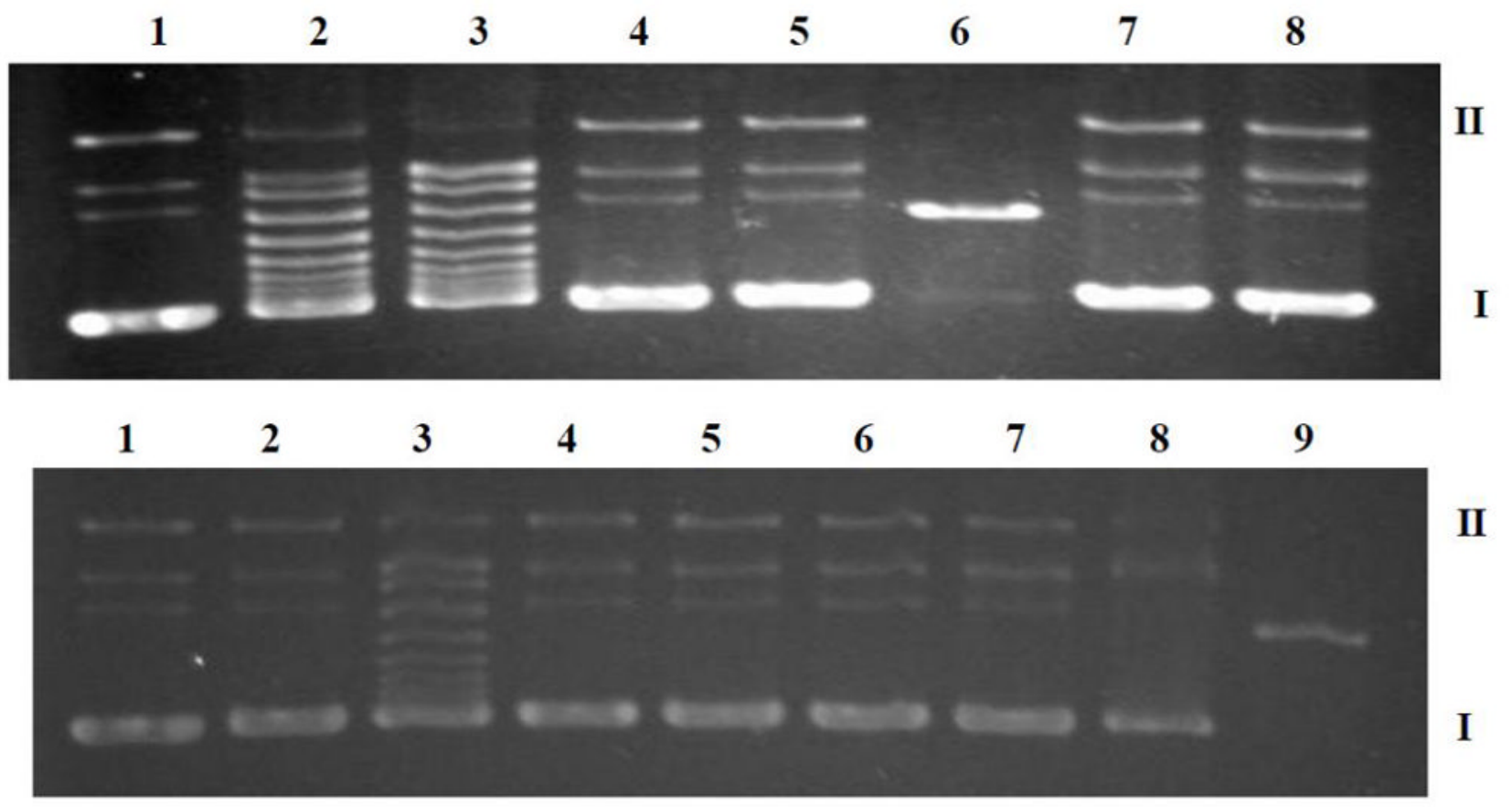

Figure 6.

Gel electrophoresis diagram for the interaction of 3 (A) and 4 (B) with human topoisomerase II. (A) Lane 1: DNA (pHOT1 - $12.5 \mathrm{ng} / \mu \mathrm{L}$ ); Lane 2: DNA \& Enzyme; Lane 3: DNA, Enzyme \& DMSO; Lanes 4,5, 8: Ru concentrations 20, 30, $100 \mu \mathrm{M}$; Lane 6: Linear DNA Marker Lane 7: etoposide; (B) Lane 1: DNA (pHOT1 - $12.5 \mathrm{ng} / \mu \mathrm{L}$ ); Lane 2: DNA \& Enzyme; Lane 3: DNA, Enzyme \& DMSO; Lanes 4-7: Ru concentrations 20, 30, 50, $100 \mu \mathrm{M}$; Lane 8: etoposide; Lane 9: Linear DNA Marker 


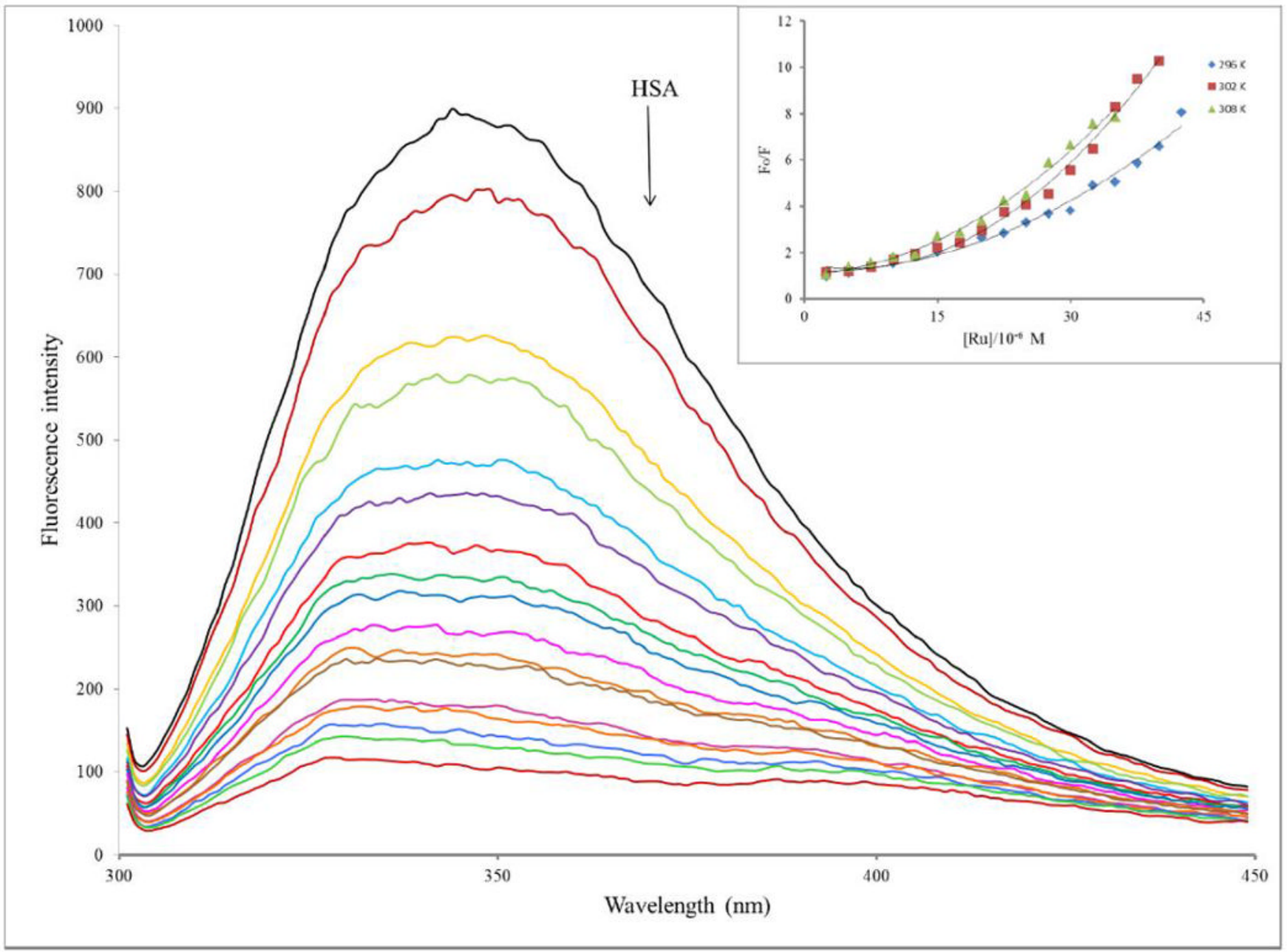

Figure 7.

Emission spectra of the HSA in the presence of increasing amounts of $\mathbf{3}, \lambda_{\mathrm{ex}}=295 \mathrm{~nm}$, $[\mathrm{HSA}]=5.0 \mu \mathrm{M}$ and [3]: $0-35 \mu \mathrm{M}$ (top-to-bottom in $2.5 \mu \mathrm{M}$ increments). Temperature $=$ 296 K. The inset is Stern-Volmer quenching plots. 


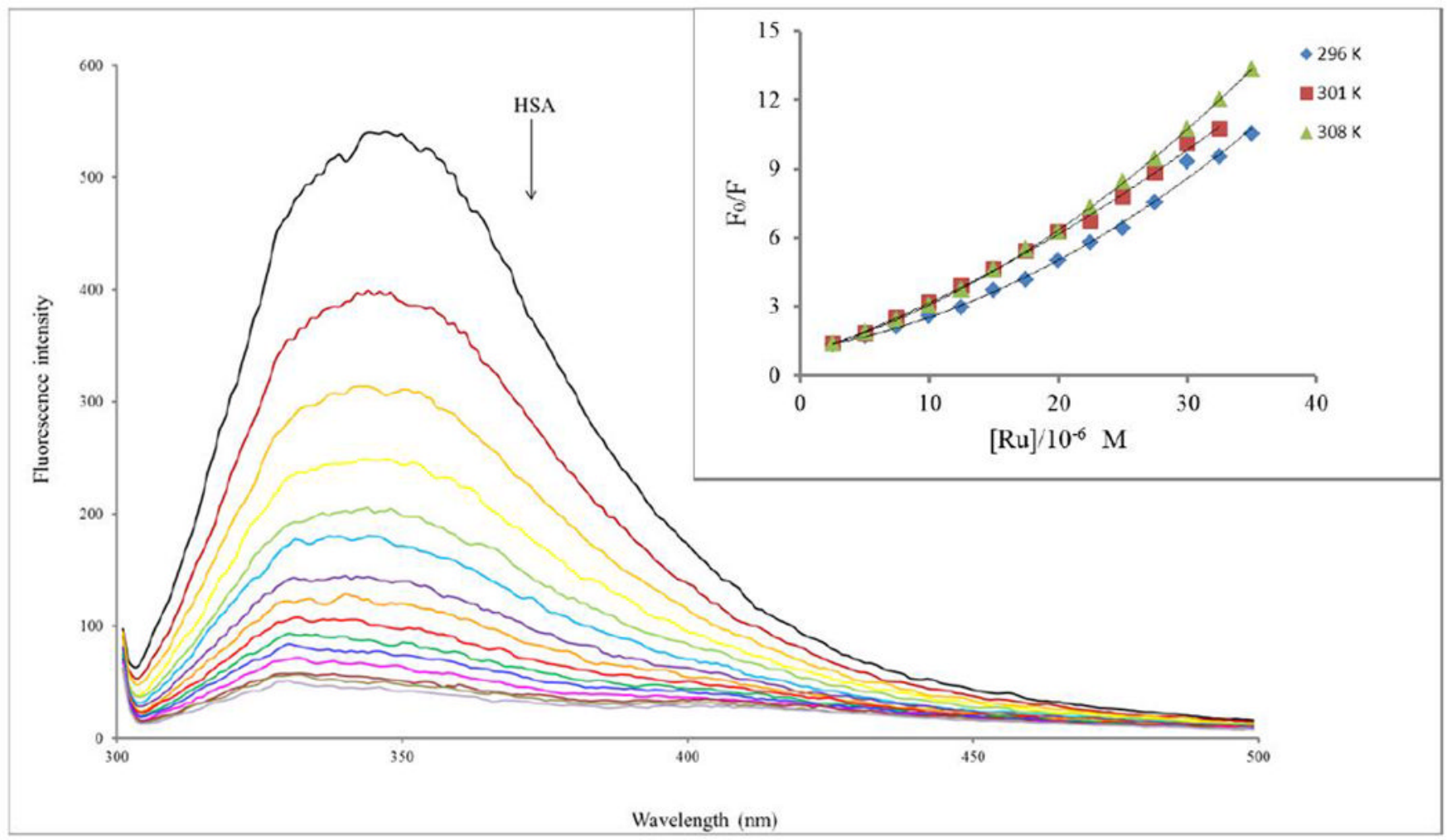

Figure 8.

Emission spectra of the HSA in the presence of increasing amounts of $4, \lambda_{\mathrm{ex}}=295 \mathrm{~nm}$, $[\mathrm{HSA}]=5.0 \mu \mathrm{M}$ and [4]: $0-40 \mu \mathrm{M}$ (top-to-bottom in $2.5 \mu \mathrm{M}$ increments). Temperature = $296 \mathrm{~K}$. The inset is Stern-Volmer quenching plots. 
Table 1

Selected crystallographic and refinement data for $4,\left[\left(\eta^{6} p\right.\right.$-cymene $\left.) \mathrm{Ru}(\mathrm{pPhTSC}) \mathrm{Cl}\right] \mathrm{Cl}$

\begin{tabular}{|c|c|c|}
\hline Parameter & Value & \\
\hline Empirical formula & $\mathrm{C}_{25} \mathrm{H}_{27} \mathrm{Cl}_{2} \mathrm{~N}_{3} \mathrm{O}_{2} \mathrm{RuS}$ & \\
\hline Formula weight & 605.53 & \\
\hline $\mathrm{T}(\mathrm{K})$ & $296(2) \mathrm{K}$ & \\
\hline Wavelength $(\AA)$ & $0.71073 \AA$ & \\
\hline Crystal system & Monoclinic & \\
\hline Space group & $\mathrm{P} 21 / \mathrm{n}$ & \\
\hline \multirow[t]{3}{*}{ Unit cell dimensions } & $a=14.9344(17) \AA$ & $\alpha=90^{\circ}$. \\
\hline & $\mathrm{b}=8.6668(10) \AA$ & $\beta=102.5730(10)^{\circ}$ \\
\hline & $\mathrm{c}=20.910(2) \AA$ & $\gamma=90^{\circ}$. \\
\hline Volume $\left(\AA^{3}\right)$ & $2641.5(5) \AA^{3}$ & \\
\hline $\mathrm{Z}$ & 4 & \\
\hline Density $_{\text {calc }}\left(\mathrm{Mg} / \mathrm{m}^{3}\right)$ & 1.523 & \\
\hline Absorption coefficient $\left(\mathrm{mm}^{-1}\right)$ & $10.902 \mathrm{~mm}^{-1}$ & \\
\hline Crystal size $\left(\mathrm{mm}^{3}\right)$ & $0.30 \times 0.21 \times 0.13 \mathrm{~mm}^{3}$ & \\
\hline$\theta$ range & $1.53-26.37^{\circ}$ & \\
\hline Index ranges & $-18 \leq \mathrm{h} \leq 18,-10 \leq \mathrm{k} \leq 10,-26 \leq 1 \leq 26$ & \\
\hline No. reflections collected & 27175 & \\
\hline No. independent reflections & $5704[\mathrm{R}(\mathrm{int})=0.0280]$ & \\
\hline Absorption correction & Numerical & \\
\hline Data/rest/param & $5402 / 0 / 322$ & \\
\hline GOF $F^{2}$ & 1.040 & \\
\hline Final $R$ indices; $[\mathrm{I}>2 \sigma(\mathrm{I})]$ & $\mathrm{R}_{1}=0.0252 ; \mathrm{wR}_{2}=0.0618$ & \\
\hline $\mathrm{R}$ indices (all data) & $\mathrm{R}_{1}=0.0330 ; \mathrm{wR}_{2}=0.0673$ & \\
\hline $\mathrm{CCDC}$ & 798099 & \\
\hline
\end{tabular}


Table 2

Selected bond lengths $[\AA]$ and angles $\left[^{\circ}\right]$ for $\mathbf{4},\left[\left(\eta^{6} p\right.\right.$-cymene $\left.) \mathrm{Ru}(\mathrm{pPhTSC}) \mathrm{Cl}\right] \mathrm{Cl}$

\begin{tabular}{llll}
\hline $\mathrm{Ru}(1)-\mathrm{C}(16)$ & $2.213(2)$ & $\mathrm{Ru}(1)-\mathrm{Cl}(1)$ & $2.4100(6)$ \\
$\mathrm{Ru}(1)-\mathrm{C}(17)$ & $2.166(2)$ & $\mathrm{Ru}(1)-\mathrm{N}(3)$ & $2.1306(17)$ \\
$\mathrm{Ru}(1)-\mathrm{C}(18)$ & $2.169(2)$ & $\mathrm{Ru}(1)-\mathrm{S}(1)$ & $2.34926(6)$ \\
$\mathrm{Ru}(1)-\mathrm{C}(19)$ & $2.270(2)$ & $\mathrm{N}(1)-\mathrm{Ru}(1)-\mathrm{S}(1)$ & $82.38(5)$ \\
$\mathrm{Ru}(1)-\mathrm{C}(20)$ & $2.239(2)$ & $\mathrm{N}(1)-\mathrm{Ru}(1)-\mathrm{Cl}(1)$ & $87.21(5)$ \\
$\mathrm{Ru}(1)-\mathrm{C}(21)$ & $2.174(2)$ & $\mathrm{S}(1)-\mathrm{Ru}(1)-\mathrm{Cl}(1)$ & $86.97(2)$ \\
\hline
\end{tabular}


Table 3

Binding parameters for the interaction of $\mathbf{3}$ and $\mathbf{4}$ to the ct-DNA

\begin{tabular}{ccccc}
\hline \multicolumn{3}{c}{$\mathbf{3}$} & \multicolumn{2}{c}{$\mathbf{4}$} \\
\hline Temperature (K) & $\mathbf{K}_{\mathbf{a p p}} / \mathbf{1 0}^{\mathbf{3}}\left(\mathbf{M}^{-\mathbf{1}}\right)$ & $\begin{array}{c}\mathbf{K}_{\mathbf{S V}} / \mathbf{1 0}^{\mathbf{3}}\left(\mathbf{M}^{-\mathbf{1}}\right) \\
\left(\mathbf{R}^{\mathbf{2}}\right)\end{array}$ & $\mathbf{K}_{\mathbf{a p p}} / \mathbf{1 0}^{\mathbf{3}}\left(\mathbf{M}^{\mathbf{- 1}}\right)$ & $\begin{array}{c}\mathbf{K}_{\mathbf{S V}} / \mathbf{1 0}^{\mathbf{3}}\left(\mathbf{M}^{\mathbf{- 1}}\right) \\
\left(\mathbf{R}^{\mathbf{2}}\right)\end{array}$ \\
\hline 293 & 3.97 & 8.84 & 4.07 & 9.10 \\
& & $(0.995)$ & & $(0.992)$ \\
303 & 4.03 & 8.87 & 5.63 & 11.4 \\
& & $(0.998)$ & & $(0.997)$ \\
\hline
\end{tabular}




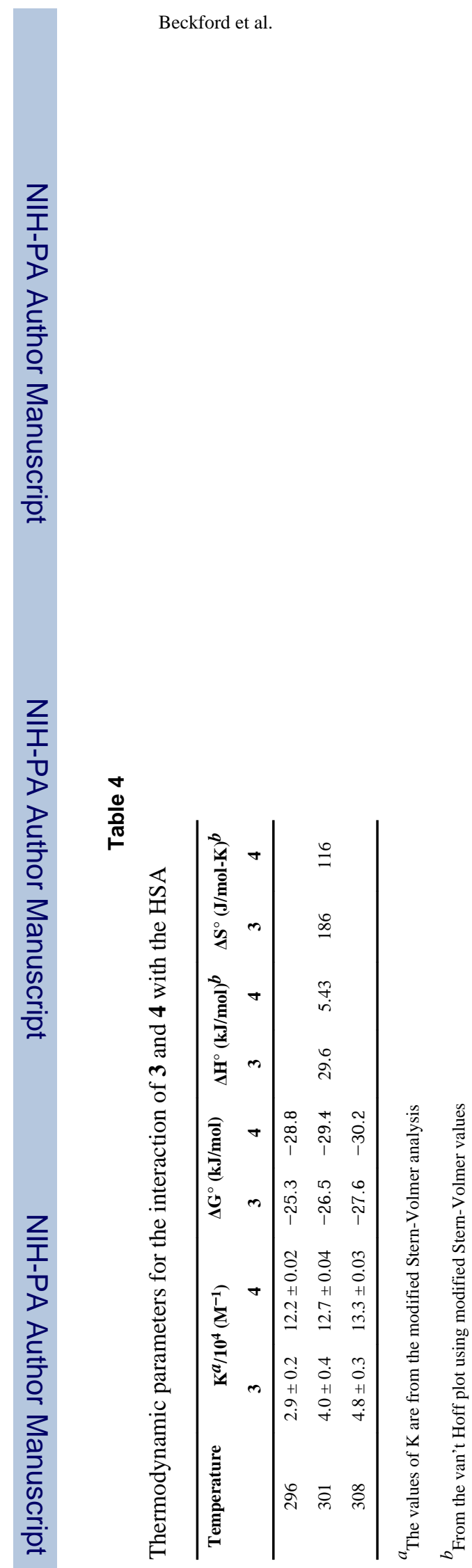

J Inorg Biochem. Author manuscript; available in PMC 2012 August 1. 


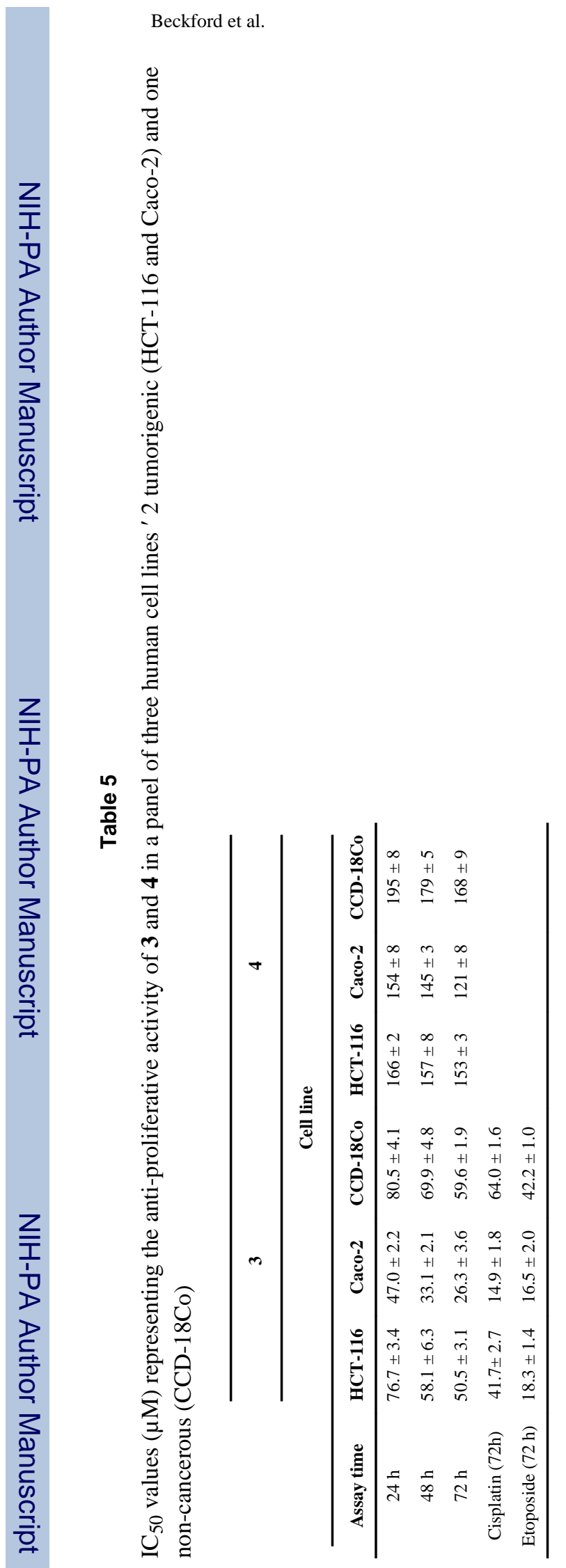

Page 30 